\title{
MODEL FOR THE SUPPLY CHAIN MANAGEMENT BASED ON THE INTERVAL TYPE-2 FUZZY NUMBERS AND THE TOPSIS METHOD
}

\author{
Danijela Tadic* and Aleksandar Djordjevic \\ Faculty of Engineering, University of Kragujevac, Kragujevac, The Republic of Serbia
}

\begin{abstract}
The Performance improvement that leads to an increase in business efficiency, both for the enterprises integrated in the supply chain and the entire supply chain, represents one of the basic strategic management problems. A solution to this problem, among other things, can be obtained by measuring and improving the performance of the supply chain, which simultaneously represents the basic purpose of this research study. The relative importance of performances and the values of their key performance indices are assessed by decision-makers. Their assessments are described by linguistic variables, which are modelled by interval fuzzy numbers type-2. The relative importance of performance is obtained by defining the fuzzy matrix of the relative importance of each pair of performances. The weight values of performances are calculated by means of the eigenvector method. Performance values are calculated by using the fuzzy middle-value operator. The rank of the enterprises, with respect to all of the considered performances as well as their weights, is determined by applying conventional TOPSIS. The ranking of the enterprises integrated in the supply chain can be marked as the main result of the research. On the basis of the obtained rank, appropriate measures can be taken to improve the performance of those enterprises that are rated the worst by respecting all the observed performances. The proposed model has been tested on the real life data from the automotive supply chain operating in Central Serbia.
\end{abstract}

Keywords: supply chain performance, interval type-2 fuzzy numbers, fuzzy AHP, TOPSIS, management measures

JEL Classification: C69, L62

\section{INTRODUCTION}

Supply chain (SC) management represents one of the most important issues, both in the practical and the

* Correspondence to: D. Tadic, Faculty of Engineering, University of Kragujevac, Sestre Janjic 6, 34000 Kragujevac, The Republic of Serbia; e-mail: galovic@kg.ac.rs theoretical domains. The considered issue is very complex and consists of a number of sub-problems. One of the sub-problems that has a critical impact on the effectiveness and competitive advantage of the SC is measuring and continuously improving the performance of the SC. This issue is especially important for the automotive industry SC that may 
significantly contribute to the sustainable economic development of each country, especially in developing countries. The automotive industry can be seen as a potential stimulus for entrepreneurship by creating new markets and developing a number of the jobs that require higher skills and knowledge. In other words, the enhancement of the efficiency and effectiveness of the SC business in the automotive industry leads to the development of the region which the SC exists in, as well as the development of entire countries.

The subject matter of the research conducted in this paper is the evaluation and ranking of the enterprises involved in the LS, respecting the LS performance. The evaluation of the SC performances and their Key Performance Indicators (KPIs) can be obtained based on decision-makers' assessments. They base their assessments on their knowledge, experience, and evidence data. Decision-makers use linguistic statements to describe the values of the existent uncertainties. It is a well-known fact that it is far easier for decision-makers to express their knowledge and experience in a natural language than to map them into a scale of measures. The concept of the linguistic variable has been introduced by L. Zadeh (1975), and it was defined as the variable whose values are words, and not numbers. The modelling of linguistic variables can be carried out by applying various theories, such as the probability theory, the theory of fuzzy sets (Zimmerman, 2001), and the theory of rough sets (Pawlak, 1998). As is well known, the modelling of uncertain data by random variables requires a large number of relevant data from the records. Due to a rapid and continuous change in the environment, to provide enough accurate data can be said to be almost impossible. The rough set theory (Pawlak, 1998) can be efficiently used to analyze uncertain and incomplete information modelled by a closed interval. This can be identified as the main advantage of the rough sets theory in relation to the fuzzy sets theory (Zimmerman, 2001), in which uncertainties are described by the function of the distribution of possibilities, although, by comparing the rough sets theory and the fuzzy sets theory, the fuzzy sets theory can be said to have advantages in the modelling of inaccurate and vague data (Zhai, Khoo \& Zhong, 2009). In this paper, all uncertainties are modelled by applying the interval type-2 fuzzy numbers that represent a special case of generalized type-2 fuzzy sets. It should be emphasized that generalized type-2 fuzzy sets require huge and complex mathematical, and therefore do not reflect bigger changes in describing and modelling the uncertainties that exist in real problems.

The main objectives of the research study presented in this paper are to rank companies within the supply chain, whereas the derived objectives of the research are to identify the performance of the SC and its KPIs, the modelling of uncertainties in the relative importance of performances and the values of their KPIs by means of interval type-2 triangular fuzzy numbers (Chen \& Lee, 2010; Kahraman, Öztayşi, Sar1 \& Turanoğlu, 2014; Zhang \& Zhang, 2017), determining the weights of performances by applying the relative importance of performances, determining the ranks of the enterprises that are integrated in the SC by using the TOPSIS method and undertaking appropriate management initiatives in order to improve the performances of the enterprise, which is further propagated so as to increase the effectiveness of the business SC and its competitive advantages.

The basic hypothesis set out in this paper may be expressed as follows: the priority of the measures that should lead to the improvement of the performances of the enterprises integrated in the SC can be based on the ranking of the considered enterprises.

In literature, a large number of developed methods can be found for measuring and improving the performances of the enterprises which different economic activities are carried out in. However, there are almost no papers that consider the problem of assessing the enterprises that are connected in the SC with the respectability of the SC performances.

Motivation for the research originates from the above-mentioned fact and the assumptions that the application of precise methods for the evaluation of the enterprises integrated in the SC can provide more accurate results, on the basis of which measures for improving the business operations of the SC are defined. 
The paper is organized in the following manner: abrief review of the relevant literature is provided in Section 2. The representation of the SC performances and their KPIs is shown in Section 3. The modelling of the existing uncertainties and the proposed algorithm are accounted for in Section 4. The proposed procedure is illustrated by the data obtained in the automotive SC industry that operates in a real environment. The conclusions are presented in Section 5.

\section{LITERATURE REVIEW}

A brief review of the literature related to the discussed problem is given in this section. As is known, SC management is based on the determination, measurement, and the improvement of the performances of SCs and their KPIs. A. D. Neely, M. Gregory and K. Platts (1995) suggest that the continuous monitoring of performance values and taking measures based on the performance values can lead to the increased effectiveness and efficiency of SC management.

In the traditional SC management approach, management teams are commonly focused only on a single performance, most often on costs. By measuring and improving only one SC performance, it is not possible to achieve the improvement of all or at least the majority of the strategic goals defined at the SC level. In literature, there are numerous and diverse approaches proposed for solving the problem of determining the SC performances and its KPIs. Some authors believe that by determining the performance of any organizational system it is possible for the SC to be based on the results of the best practice (Coccoa \& Alberti, 2010). J. Anitha (2014) believes that the identification of the performances should be based on the analysis of the data obtained by a survey. The validity of the results (in this case, it is a set of the SC performances) can be confirmed by applying a regression analysis. B. M. Beamon (1999) grouped all SC performances into the three groups: the performance resources, outputs and flexibility. Respecting the requirements of ISO 9001: 2008 and the results of good practice in (Nestic, Djordjevic,
Puskaric, Zahar Djordjevic, Tadic, \& Stefanovic, 2015; Tadić, Đorđević, Erić, Stefanović, \& Nestić, 2017), the production SC performances are defined. In the paper (Ramesh \& Kodali, 2012), the results obtained from the numerous literary sources were summarized, and a list of performances for the lean production SC was proposed. In this paper, the SC performance is determined according to the recommendations defined in the Supply-Chain Operations Reference (SCOR) (Bolstorff \& Rosenbaum, 2003) model, and they are described in Section 3. It is a well-known fact that performance values can be obtained by measuring or that they may be based on the decisionmaker's decision.

As is known, performance values can be obtained by measuring or they can be based on the decisionmaker's assessment. Decision-makers can use predefined measuring scales to reflect their stands onto a set of real numbers. In literature, many measuring scales are used, such as the standard scale of measures in (Coccoa \& Alberti, 2010). The mapping of assessment onto a set of linguistic statements instead of a set of precise numbers is far closer to the human way of thinking and, therefore, is more precise. Bearing this fact in mind, many authors suggest the use of linguistic expressions to describe performance values (Nestić et al, 2015). The modelling of linguistic expressions in the paper (Nestić et al, 2015; Tadić et al, 2017) is based on the theory of fuzzy sets (Zimmeramn, 2001; Dubois \& Prade, 1980). In other words, these linguistic expressions are modelled by applying triangular fuzzy numbers. In (Nestic et al, 2015), the task of the assessment of the relative importance of each performance is set as a fuzzy group decision-making problem. The aggregated value of the decision-maker's assessments was obtained by using the fuzzy weighted aggregation operator (FOWA) that is widely used in literature (Merigó \& Casanovas, 2008). The overall value of each performance is calculated as a product of relative importance and the estimated value, and is described by the triangular fuzzy number based on the fuzzy algebra rules (Dubois \& Prade, 1980).

The numerous performance measurement methods developed in different mathematical and logical 
frameworks can be found in literature. These methods have been developed so as to measure the performances of the organizational systems that differ between themselves in their size, the economic branch which they belong to, the way of connection, and so on. Furthermore, a brief retrospective of some of the performance measurement methods is shown.

The most widely used method for measuring performances in the enterprises in which different economic activities are carried out is the Balanced Scorecard (BSC), developed by S. R. Kaplan and P. D. Norton (2008). By applying this approach, it is possible to determine performance values in different perspectives. In this way, a balance between long- and short-term goals, as well as that between financial and non-financial performances, is possible to establish. The BSC approach makes the transformation of strategic goals into a performance set possible. It is necessary to apply the BSC approach at each level of management in order to achieve better results of performance measuring (Behery, Jabeen, \& Parakandi, 2014). In this manner, goal setting, setting priorities for the achievement of the goal and the allocation of the resources are significantly simpler compared to the other methods for performance measurement presented in literature. With the use of the BSC approach it is possible for managers to relatively easily maintain or improve the defined management strategy.

M. Hakimollahi, S. J. Naini, M. Bagherpour, S. Jafari and A. Shahmoradi (2012) have developed a method for measuring the performances based on the BSC approach with the fuzzy-interferential mechanism. The KPI performance values defined in each BSC perspective are determined by applying the fuzzy if-then rules. The assessment made by experts of the KPIs values was determined based on their knowledge and experience. In (Nestić et al, 2015) the rank of KPIs at the level of all of the considered processes, simultaneously respecting all the enterprises, was obtained by using the continuous fuzzy numbers comparison method (Baas \& Kwakernaak, 1977; Dubosi \& Prade, 1980).

Many authors suggest that the determination of performance values can be defined as the task of multi-criteria decision-making (Saranga \& Moser, 2010; Feili et al, 2011). The estimates of the relative importance of KPIs at the level of each performance and their values were obtained by conducting a survey in (Feili et al, 2011), involving decision-makers from different enterprises belonging to the same industrial branch. The decision-makers responded to the questions defined in the survey by using the predefined linguistic expressions, modelled with triangular fuzzy numbers. The aggregated value of the decision-makers' assessments was calculated as the geometric mean of the assessments that were obtained from all of the experts participating in the survey. The weighted aggregate values of the KPIs within each performance were calculated as weight and assessment value products. The KPIs priority at the level of each performance was obtained by using the fuzzy Analytical Hierarchical Process (AHP), developed in (Chang, 1996). H. Saranga and R. Moser (2010) suggest the use of the Data Envelopment Analyses (DEA) method for determining performance values. In (Tadić et al, 2017), uncertainties in the relative importance of performances and their values are described by the linguistic expressions modelled with a triangular fuzzy numbers. The fuzzy pairwise comparison matrix of the relative importance of performances was set. The processing of uncertainty was carried out by using the extended analysis method, developed in (Chang, 1996). The normalized performance values were obtained by applying the linear normalization procedure (Shih, Shyur \& Lee, 2007). The elements of the weighted normalized fuzzy decision matrix were calculated as a calculated weight and an assessed performance product. The fuzzy positive ideal solution, the fuzzy negative ideal solution and the coefficient of approximation, on the basis of which the performance ranges were determined, were calculated as they were with the conventional Technique for Order Preference by Similarity to Ideal Solution (TOPSIS), developed in (Yoon \& Hwang, 1981).

According to the requirements of ISO 9001: 2015, it is necessary to perform the continuous improvement of business processes. This is achieved, among other things, by improving the performance of the processes themselves. In this way, the appointed business goals can be almost fully realized. Performance 
improvement is achieved by applying the appropriate management measures that are either defined in the standard by the quality system procedures implemented in enterprises or the same may be defined by decision-makers, on the basis of their own knowledge and experience. In the papers analyzed in this section, the priority of the measures corresponds to the priority of the enterprises integrated in the SC.

By comparing the proposed model with the models that have been developed and shown in this paper, the differences can be noted and they are further discussed. On the basis of the obtained results, it is possible to clearly see the advantage of the model developed in this paper, in relation to the papers published in literature.

Performance determination is a task of great importance because it affects the entire decisionmaking process. In this paper, SC performances are determined on the basis of literature (Bolstorff \& Rosenbaum, 2003) and it can be assumed that the performance list is more consistently defined than in the other applied methods presented in (Coccoa \& Alberti, 2010; Anitha, 2014; Nestić et al, 2015).

The relative importance of KPIs and their values are assessed by decision-makers by using the predefined linguistic expressions (Feili et al, 2011; Nestić et al, 2015). The use of linguistic variables can be said to allow decision-makers to better express their opinion, rather than use a scale of measures, as presumed in (Kaplan \& Norton, 2008; Coccoa \& Alberti, 2010). Uncertainties in the relative importance of performances or KPIs, as well as their values, are described by the interval type-2 fuzzy numbers (Chen \& Lee, 2010; Kahraman et al, 2014; Zhang \& Zhang, 2017). It is assumed that the interval type-2 fuzzy numbers can better describe uncertain and imprecise data (Chen \& Lee, 2010) when it is impossible to determine the shape of the distribution of the possibilities function of the type1 fuzzy number in the exact way (Castillo \& Melin, 2012). Based on these assumptions, the modelling of uncertainty in this paper was performed in an improved way than it is the case in the papers found in literature (Feili et al, 2011; Nestić et al, 2015). It is closer to the human way of thinking to express the relative importance of performances by applying the fuzzy matrix of pairs, rather than by applying the direct estimation method (Nestić et al, 2015). In this paper, the pair-wise fuzzy matrix of the relative importance of the performances was set (Feili et al, 2011). Also, in the proposed method, the consistency of the decision-maker's judgment was carried out by the defuzzification of the interval type-2 phase numbers in the first step (Kahraman et al, 2014), and then in the second step, the method of the eigenvector was applied, as defined in the conventional AHP method (Saaty, 1990), so as to verify the consistency of the decision-makers' judgments. The developed procedure presents one of the differences between the proposed method for determining the weight of the performances and the methods presented in (Feili et al, 2011). The management measures to be taken in order to improve the performances of enterprises and the SC are based on the ranking of the enterprises. In this paper, as in all of the analyzed papers found in literature, management measures are considered to be defined by decision-makers based on their knowledge and experience. In the paper (Nestić et al, 2015), the application of the genetic algorithm determines the optimum value of improvement for the selected performance, which provides an opportunity for decision-makers to better select the management initiatives. The main disadvantage of the proposed method is the lack of a procedure for determining the optimum value of performance improvement.

\section{SUPPLY CHAIN PERFORMANCE}

In this paper, the problem of the ranking of the enterprises integrated in the SC with respect to their performances is considered. The SC is assumed to consist of one focal organization and a larger number of the enterprises that can be viewed as the focal organization providers. Such a structure is common for the automotive industry SC. Within this assumption, it can be said that almost all the products used in the assembly process within the focal organization are produced in providing enterprises. The effectiveness of each enterprise's processes affects the efficiency of the final assembly process, as well as the realization of both the operational and the strategic 
objectives of the automotive industry SC. Formally, the considered enterprises can be represented by a set of indices $E=\{1, \ldots, e, \ldots, E\}$. The total number of the companies considered is $E$, whereas each enterprise index is denoted as $e, e=1, \ldots, E$.

The degree of the achievement of the SC business objectives can be determined based on the value of the performances of the enterprises integrated in the $\mathrm{SC}$. The SC performances are defined in appropriate standards or models (Bolstorff \& Rosenbaum, 2003). In this paper, the SC performances are defined by SCOR (Bolstorff \& Rosenbaum, 2003), which is widely used in literature and in practice. In addition, the SC performances are briefly described, and they also represent the performances of the enterprises that are integrated in the considered SC.

\section{Complexity}

The concept of complexity has been studied in the framework of the graph theory (Bezuidenhout, Bodhanya, Sanjika, Sibomana \& Boote, 2012), the SC theory (Pathak, Day, Nair, Sawaya \& Kristal, 2007), and other theories. Hence, there is no unique definition of the complexity of the SC term. C. Y. Cheng, T. L. Chen and Y. Y. Chen (2014) implicated that the SC complexity was influenced by a number of factors, such as the size, the degree, and the intensity of the relationships between entities. Quite minor changes in complexity are known to lead to a reduction in the degree of the accomplishment of the placed business goals. The complexity value at the level of each SC entity can be determined based on the estimated values of the KPIs of the SC complexity.

In this paper, the KPIs are determined according to L. Xu, Y. Li, K. Govindan and X. Xu (2015), and they are as follows: (1) the complexity of the environment, (2) the complexity of the production process, (3) operational complexity, and (4) the complexity arising due to the integration of the entities. The value of the complexity of the environment can be assessed with respect to the data on the demand variability. Taking into consideration the information about the complexity of receiving and storing both raw materials and semi- finished products, the complexity of technological procedures and the methods of the quality control of the processes, semi-products and products, it is possible to estimate the value of the complexity of the production process. The value of operational complexity can be determined by respecting the data on complexity, regarding the processes of production planning and control, internal transport, quality control methods, necessary knowledge and skills, and others. The complexity that arises from the integration of the SC entities is influenced by the number of such entities, the number of the hierarchical levels of each entity, and the links that exist between the entities within the SC.

\section{Uncertain Demand}

In recent decades, in almost all SCs, it has been possible to see that the deviation between a planned quantity and real demand has been on an increase. These deviations have appeared due to the many changes that have been occurring: (a) in SCs, according to T. Maiti and B. C. Giri (2016), which occur due to the lack of relevant information about the changes related to production and demand costs over time; and (b) in the environment, e.g. the development and rapid application of new technologies, customer demand changes, and so forth. Uncertain demand leads to many difficulties in planning the production of the enterprises associated with the SC (Felfel, Ayadi \& Masmoudi, 2016).

A number of KPIs have been considered in literature, on the basis of which the value of uncertain demand can be determined. In this paper, the KPIs of uncertain demand are determined according to C. Y. Wong and S. Boon-itt (2008), and they are as follows: (1) customer uncertainty, (2) technological uncertainty, (3) the economic situation, (4) market competitiveness, and (5) law regulation. The decision-makers have based their assessments regarding the first KPI values on the pieces of information related to the types and quantities of the products required by customers, changes in delivery times, and the delivery flexibility. Every complete SC can be said to be characterized by a lack of reliable information which decision-makers 
can assess the value of customers' uncertainty on. The uncertainty of demand can be significantly reduced if the SC is customer-, rather than productoriented (Frohlich \& Westbrook, 2002). Technological uncertainty is mostly affected by the technological level of a company. It is known that the higher the technological level, the lower a technological uncertainty. This also applies vice versa. The assessment of the economic situation (Bolstorff \& Rosenbaum, 2003) is related to the market growth, the gross domestic product, the unemployment rate, the mortality rate, and so on. The value of the market competitiveness can be estimated by taking into consideration the price of a product by a competitive $\mathrm{SC}$, the time of the delivery of the final products, and the degree of the innovation of competitive SCs (Pal \& Kumar, 2008). The business of the enterprise in the SC must be in accordance with valid legal propositions.

\section{Quality}

Predicting demand and determining the product quality are based on the requirements that come from an environment that is rapidly and continuously changing. In order to meet all the requirements, it is necessary that the quality management system should be integrated in any enterprise that is part of the SC. In this way, it is possible to achieve an improvement in the production process in each company, and therefore in the SC as well.

In literature, different KPIs classifications of the considered performances can be found (Bolstorff \& Rosenbaum, 2003; Sadikoglu \& Zehir, 2010). In this paper, those KPIs that are defined in (Bolstorff \& Rosenbaum, 2003) are adopted: (1) the capability, (2) the critical success factors, (3) the strategic components, and (4) the operational components. Many researchers suggest that capacity assessment depends not only on a product quality, but also on the reliability of the delivery, the trust that exists between the focal organization and the enterprise, etc. The value of the critical success factors is assessed according to the results of the integration related to external stakeholders (Kuei \& Madu, 2001), as well as to the quality of leadership in the SC (Kupers,
2000). The values of a KPI, which is designated as a strategic component, are assessed with respect to organizational culture and technology management. The assessment of the value of the operational component is based on the information about the extent to which the demand of the focal organization and the volume of the production of the networked enterprises differ, which the company development policies are, and so on and so forth.

\section{Added Value}

Added value is defined as the difference between the price of the product and the cost of production. In recent years, the management of many SCs considers this to be one of the most important SC performances (Presutti, 2003). Based on the results from literature, it can be concluded that the added value of almost every product varies very much over time, and that these variations occur primarily due to changes in production costs.

The KPIs of this performance are defined according to the literature data: (1) the average value of the income of the stakeholder, (2) an increase in the profit, (3) the utilization of the property in possession, (4) communication within the SC and with customers, and (5) the SC's social responsibility.

\section{MODELING OF UNCERTAINTIES}

This section presents the method for the modeling of uncertain and imprecise data in the relative importance of the performances and their values at the level of the considered enterprises. The interval fuzzy set of the type- 2 is represented by the function of the distribution of possibilities. The upper and lower functions of the interval type- 2 fuzzy set are the functions of the distribution of the possibilities of the fuzzy set defined in (Dubois \& Prade, 1980; Zimmeramann, 2001). The parameters of this function are the shape, granulation, and domains. The distribution of the functions of opportunities is determined on the basis of subjective assessments made by decision-makers, and the same should 
reflect the knowledge of such decision-makers of the uncertainties involved. In literature, trapezoidal and triangular interval type-2 fuzzy numbers for the description of numerous and varied uncertainties (Chen \& Lee, 2010; Kahraman et al, 2014; Zhang \& Zhang, 2017) are the most commonly used ones. Granulation is defined as the number of the fuzzy sets that are associated with each considered uncertainty. Some authors (Lootsma, 1997) believe that the decision-maker can use up to seven linguistic statements to describe uncertainty. In this paper, the relative importance of performances can be described by the five linguistic expressions and their values at the level of each enterprise by the application of the seven linguistic expressions modeled by the interval type-2 triangular fuzzy numbers. The domains of these fuzzy numbers are defined at a closed interval in a set of real numbers.

The Selection of Appropriate Linguistic Expressions to Assess the Relative Importance of Performances and the Values of Their KPIs

Respecting the type and the size of the problem, it was assumed that the real value of each pair of the SC performances can be adequately described by applying the five linguistic expressions modeled by the interval type-2 triangular fuzzy numbers in the following way:

very low importance - $\tilde{\tilde{W}}_{1}=((1,1,3.5 ; 1),(1,1,2,5 ; 0.75))$,

low importance - $\tilde{\tilde{W}}_{2}=((1,2,4 ; 1),(1.5,2,3.5 ; 0.75))$,

medium importance $-\tilde{\tilde{W}}_{3}=((1,3,5 ; 1),(2,3,4 ; 0.75))$,

high importance - $\tilde{\tilde{W}}_{4}=((2,4,5 ; 1),(1.5,4,4.5 ; 0.75))$ and

the highest importance $-\tilde{W}_{5}=((2.5,5,5 ; 1),(3,5,4,5 ; 0.75))$.

The domains of these interval type-2 triangular fuzzy numbers are defined on a set of real numbers within the interval [1-5]. Value 1, or Value 5, indicates that the performance $\mathrm{p}$ has the same relative importance, i.e. the highest importance, in relation to the performance $p^{\prime}, p, p^{\prime}=1, \ldots, P$, respectively.
The overlapping of the defined interval type-2 triangular fuzzy numbers used for the modeling of the relative importance of the SC performances is higher because there is insufficient knowledge of their priority.

The KPI values for each of the considered performances are described by applying the seven linguistic expressions modeled by the interval type-2 triangular fuzzy numbers, as is shown below:

very small (VM) - ((1,1,2.5;1),(1,1,2;0.6)),

small $(\mathrm{M})$ - $((1.5,3,4.5 ; 1),(2,3,4 ; 0.6))$,

almost middle (GS) - ((2.5,4,5.5;1),(3,3.5,5;0.6)),

middle (S) - ((3.5,5,6.5;1),(4,5,6;0.6)),

gotovo visoka $(\mathrm{GV})$ - $((4.5,6,7.5 ; 1),(5,6,7 ; 0.6))$,

high $(\mathrm{V})$ - $((5.5,7,8.5 ; 1),(6,7,8 ; 0.6))$ and

very high (VV) - $((7.5,9,9 ; 1),(8,9,9 ; 0.6))$.

The domains of the interval type-2 triangular fuzzy numbers used for the modeling of the performance values at the level of each enterprise are defined by a respectable standard measuring scale (Saaty, 1990). The value 1 , i.e. value 9 , indicates that the performance $p, p=1, . ., P$ has the smallest, i.e. the highest value, respectively.

\section{Constructing the Fuzzy Pairing Matrix for the Comparison of Performances}

In literature, a large number of papers can be found, in which the relative importance of the attributes in terms of which the alternatives are given by the fuzzy matrix of the relative importance of the attributes (Tadic et al, 2016). It is assumed that this way is closer to the human way of thinking than to a direct assessment. In this paper, the pair-wise fuzzy matrix of the relative importance of the performances is set, according to which the SC enterprises are evaluated. The relative importance of each pair of the criteria is assessed by the strategic management 
that makes a decision by consensus. The elements of this matrix are defined as the relative importance of the performance $p, \quad p=1, \ldots, P$ compared to the performance $p^{\prime}, p^{\prime}=1, \ldots, P, p \neq p^{\prime}$. The values of these elements are described by the previously defined linguistic expressions modeled by the interval type2 triangular fuzzy numbers (Chen \& Lee, 2010): $\tilde{\tilde{W}}_{p p^{\prime}}=\left(\left(\tilde{X}_{p p^{\prime}}^{U} ; \mu_{1}\left(X_{p p^{\prime}}^{U}\right),\left(\tilde{X}_{p p^{\prime}}^{L} ; \mu_{2}\left(X_{p p^{\prime}}^{L}\right)\right)\right)\right)$.

Type-1 triangular fuzzy numbers are marked as:

$$
\begin{aligned}
& \tilde{X}^{U}=\left(a_{p p^{\prime}}^{U}, b_{p p^{\prime}}^{U}, c_{p p^{\prime}}^{U}\right) \text { and } \\
& \tilde{X}^{L}=\left(a_{p p^{\prime}}^{L}, b_{p p^{\prime}}^{L}, c_{p p^{\prime}}^{L}\right) .
\end{aligned}
$$

The reference points of the interval type-2 triangular fuzzy numbers are denoted as:

$$
a_{p p^{\prime}}^{U}, b_{p p^{\prime}}^{U}, c_{p p^{\prime}}^{U} a_{p p^{\prime}}^{L}, b_{p p^{\prime}}^{L}, c_{p p^{\prime}}^{L} .
$$

The distribution function of the higher or lower interval type-2 triangular fuzzy numbers is denoted

as $\mu_{1}\left(\tilde{X}_{p p^{\prime}}^{U}\right)$, i.e., $\mu_{2}\left(\tilde{X}_{p p^{\prime}}^{L}\right)$, respectively.

If the relative importance of the performance $p^{\prime}$ is greater than the relative importance of the performance $p$, then the value of the element to the pair-wise fuzzy matrix of the relative importance of the performances can be described as:

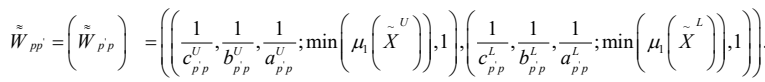

Based on the experience and results of good practice, it can be argued that decision-makers make mistakes in assessment. Therefore, it is, firstly, necessary to determine the consistency of the assessment made by strategic managers. In the first step, the pairwise fuzzy matrix of the relative importance of the performances is mapped onto the pair-wise fuzzy matrix of the relative importance of the performances whose values are precise numbers. The representative scalars of the interval type-2 triangular fuzzy numbers were obtained using the defuzzification procedure (DTriT), developed by C. Kahraman et al (2014), so that

$$
W_{p p}=\frac{\frac{\left(c_{p p^{\prime}}^{U}-a_{p p}^{U}\right)+\left(b_{p p^{\prime}}^{U}-a_{p p^{\prime}}^{U}\right)}{3}+a_{p p^{U}}^{U}+\alpha \cdot\left[\frac{\left(c_{p p^{L}}^{L}-a_{p p^{\prime}}^{L}\right)+\left(b_{p p^{\prime}}^{L}-a_{p p^{\prime}}^{L}\right)}{3}+a_{p p^{L}}^{L}\right]}{2}
$$

where $\alpha$ denotes the maximum value of the distribution function of the possibilities for the lower interval type-2 triangular fuzzy number.

In the second step, the consistency of the pairwise fuzzy matrix of the relative importance of the performances is determined by applying the eigenvector method (Saaty, 1990). Decision-makers' assessments are assumed to be consistent if the coefficient of consistency (C.I.) is less than 0.1.

\section{The Proposed Algorithm}

Step 1. Construct the fuzzy comparison matrix of the pairs of the relative importance of the performances, $\left[\tilde{W}_{p p^{\prime}}\right]_{P x P}$, and determine the weight of the

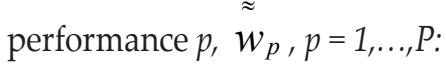

$$
\approx \tilde{w}_{p}=\frac{\approx}{\sum_{p=1}^{P} \tilde{r}_{p}}
$$

where:

$$
\tilde{r}_{p}=\left(\left(\sqrt[p]{\prod_{p=1}^{p} a_{p p}^{U}}, \sqrt[p]{\prod_{p=1}^{p} b_{p p}^{U}}, \sqrt[p]{\prod_{p=1}^{p} c_{p p}^{v}} ; \mu_{1}\left(b_{p p}^{U}\right)\right),\left(\sqrt[p]{\prod_{p=1}^{p} a_{p p}^{L}}, \sqrt[p]{\prod_{p=1}^{p} b_{p p}^{L}}, \sqrt[p]{\prod_{p=1}^{p} c_{p p}^{L}} ; \mu_{2}\left(b_{p p}^{L}\right)\right)\right)
$$

The performance weight is described by the interval type-2 triangular fuzzy number.

Step 2. Assess the KPI values of each performance at the level of each enterprise,

$$
\stackrel{\tilde{V}}{V}_{j e p}, j=1, . ., J_{p} ; e=1, \ldots, E ; p=1, \ldots, P
$$


Step 3. Determine the aggregated performance $p$ value:

$$
\tilde{z}_{e p}=\frac{\tilde{V_{j e p}}}{J_{p}} e=1, \ldots, E ; p=1, \ldots, P
$$

Step 4. Construct the decision matrix,

$$
\begin{aligned}
& {\left[\tilde{\tilde{d}}_{e p}\right]_{E x P} \text {, so that: }} \\
& \tilde{d}_{e p}=\tilde{w}_{p} \cdot z_{e p}
\end{aligned}
$$

The decision matrix values are described by the interval type-2 triangular fuzzy number, based on the multiplication rule defined in (Mendel \& Liu, 2017).

The representative scalar of the interval type2 triangular fuzzy number, $\tilde{\tilde{d}}_{e p}$ is obtained by applying the defuzzification procedure (Kahraman et al, 2014), $d_{e p}, e=1, . ., E, p=1, . ., P$.

The decision matrix can be written as:

$$
\left[d_{e p}\right]_{E x P}
$$

Step 5. Determine the Positive Ideal Solution (PIS), $d_{p}^{+}, p=1, \ldots, P$ and the Negative Ideal Solution (NIS), $d_{p}^{-}, p=1, \ldots, P$ while respecting the type of the performance:

a) for the beneficial type:

$$
d_{p}^{+}=\max _{e=1, . . E} d_{e p}, \quad d_{p}^{-}=\min _{e=1, . . E} d_{e p}
$$

b) for the cost type:

$$
d_{p}^{+}=\min _{e=1, . ., E} d_{e p}, \quad d_{p}^{-}=\max _{e=1, \ldots, E} d_{e p}
$$

Step 6. Calculate the Euclidean distance from PIS, $y_{p}^{+}$and NIS, $y_{p}^{-}$for each decision matrix element value:

$$
y_{p}^{+}=\sum_{p=1}^{P}\left(d_{p}^{+}-d_{e p}\right)^{2} \text { i } y_{p}^{-}=\sum_{p=1}^{P}\left(d_{p}^{-}-d_{e p}\right)^{2}
$$

Step 7. Calculate the coefficients of the approximation that is associated with each enterprise, according to the procedure developed in the conventional TOPSIS method (Yoon \& Hwang, 1981) $k_{e}$ :

$$
k_{e}=\frac{y_{p}^{-}}{y_{p}^{-}+y_{p}^{+}}
$$

Step 8. Assort the coefficients of the approximation into a decreasing set. The rank of the enterprise is determined by the $k_{e}$. values. The enterprise with the highest associated value $k_{e}$ is the considered to be the first-ranked.

\section{An Illustrative Example}

The automotive industry SC that has been the subject matter of discussion, which exists in Central Serbia, includes the focal enterprise (in which the process of the assembly of the final product is realized) and the nine big enterprises (in which the components are built, which are later installed in the final product). It should be emphasized that the revenue generated by the automotive industry SC has a major impact on the gross domestic product of each country, especially developing countries. SC performances are defined on the basis of literature recommendations (Bolstorff \& Rosenbaum, 2003). To assess the relative importance of the performances, as well as their values, appropriate questionnaires were sent to the SC's strategic management, as well as the management teams (the production manager, the quality manager, the financial manager and the supply manager) involved in the SC, respectively. The decision-makers were asked through the questionnaire to select one of the predefined linguistic expressions in order 
to assess the relative importance of each pair of the performances, and the value of each performance. All decision-makers may be assumed to have made decisions by consensus.

The fuzzy matrix of the relative importance of the pairs of the performances at the SC level is defined as follows (Step 1 of the developed Algorithm):

$\left[\begin{array}{cccc}((1,1,1 ; 1),(1,1,1 ; 1)) & 1 / \tilde{W}_{1} & 1 / \tilde{W}_{3} & 1 / \tilde{\tilde{W}}_{4} \\ \tilde{\tilde{W}}_{1} & ((1,1,1 ; 1),(1,1,1 ; 1)) & 1 / \tilde{\tilde{W}}_{2} & 1 / \tilde{\tilde{W}}_{3} \\ \tilde{\tilde{W}}_{3} & \tilde{\tilde{W}}_{2} & ((1,1,1 ; 1),(1,1,1 ; 1)) & 1 / \tilde{\tilde{W}}_{2} \\ \tilde{\tilde{W}}_{4} & \tilde{\tilde{W}}_{3} & \tilde{\tilde{W}}_{2} & ((1,1,1 ; 1),(1,1,1 ; 1))\end{array}\right]_{4 \times 4}$

The mapping of the fuzzy pair-wise matrix of the comparison of the relative importance of the performances in the pair-wise matrix of the comparison of the relative importance of the performances is performed by applying the defuzzification process, DTriT (Kahraman et al, 2014), in order to determine the consistency of the assessment of the strategic managers:

$$
\left[\begin{array}{cccc}
1 & 0.681 & 0.422 & 0.301 \\
1.468 & 1 & 0.473 & 0.422 \\
2.369 & 2.114 & 1 & 0.473 \\
3.322 & 2.369 & 2.114 & 1
\end{array}\right], \text { C.I. }=0.258
$$

Using the expressions (1) and (2), the weights of the considered performances are calculated. The procedure shown in Step 1 of the Developed Algorithm is illustrated in the case of calculating the weight of the performance, which is denoted as complexity $(p=1)$.

$$
\begin{aligned}
& \tilde{r}_{1}=((0.327,0.536,0.841 ; 1),(0.386,0.536,0.759 ; 0.75)) \\
& \sum_{p=1}^{4} \tilde{r}_{p}=((0.327,0.536,0.841 ; 1),(0.386,0.536,0.759 ; 0.75))+ \\
& +\left((0.473,0.639,1.268 ; 1),\left(0.518,0.639,0.955^{\prime} 0.75\right)\right)+ \\
& +((0.707,1.316,2.115 ; 1),(0.963,1.316,1.749 ; 0.75))+ \\
& +((1.189,2.213,3.162 ; 1),(1.456,2.213,2.817 ; 0.75))= \\
& =((2.696,4.704,7.386 ; 1),(3.323,4.705,6.2780 ; 0.75))
\end{aligned}
$$

$\tilde{w}_{1}=\frac{((0.327,0.536,0.841 ; 1),(0.386,0.536,0.759 ; 0.75))}{\left((2.696,4.704,7.486 ; 1),\left(3.323,4.705,6.280^{\prime} 0.75\right)\right)}=$ $=((0.327 / 7.486,0.536 / 4.704,0.841 / 2.696 ; 1))$,

$((0.386 / 6.280 .0 .536 / 4.705,0.759 / 3.323 ; 0.75))$

$\tilde{w}_{1}=((0.044,0.114,0.312 ; 1),(0.061,0.114,0.228 ; 0.75))$

In the same way, the weight of the other considered performances are obtained, and they are:

$\tilde{w}_{2}=((0.063,0.136,0.470 ; 1),(0.082,0.136,0.287 ; 0.75))$

\begin{tabular}{|c|c|c|c|c|c|c|c|c|c|}
\hline & \multicolumn{9}{|c|}{ Enterprise } \\
\hline & $e=1$ & $e=2$ & $e=3$ & $e=4$ & $\mathrm{e}=5$ & $e=6$ & $e=7$ & $\mathrm{e}=8$ & $e=9$ \\
\hline \multirow{4}{*}{$\frac{\frac{\vec{y}}{x}}{\frac{0}{\hat{a}}}$} & GS & $M$ & GS & $M$ & $M$ & $G S$ & $M$ & $G S$ & GS \\
\hline & GV & $S$ & GV & $S$ & $S$ & GV & $S$ & GV & GV \\
\hline & $S$ & $S$ & GV & $S$ & $S$ & GV & $S$ & GV & GV \\
\hline & GV & $S$ & V & $G V$ & GV & V & $G V$ & V & V \\
\hline \multirow{5}{*}{ 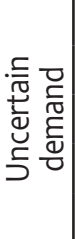 } & $M$ & $M$ & $M$ & $M$ & VM & VM & VM & VM & VM \\
\hline & $M$ & $M$ & $M$ & $M$ & VM & VM & VM & VM & VM \\
\hline & GS & GS & $M$ & $M$ & $M$ & $M$ & $M$ & VM & VM \\
\hline & $M$ & $M$ & $M$ & $M$ & $M$ & VM & VM & $M$ & $M$ \\
\hline & VM & $M$ & $M$ & VM & VM & VM & $M$ & VM & $M$ \\
\hline \multirow{4}{*}{$\begin{array}{l}\frac{\vec{\nabla}}{\bar{T}} \\
\frac{\pi}{3}\end{array}$} & $\mathrm{~V}$ & $\mathrm{~V}$ & $V V$ & $\mathrm{~V}$ & $\bar{V}$ & V & $\bar{V}$ & VV & $\mathrm{VV}$ \\
\hline & WV & VV & VV & VV & V & V & VV & V & W \\
\hline & VV & VV & VV & V & VV & V & V & V & V \\
\hline & V & V V & VV & VV & V & VV & V & VV & V \\
\hline \multirow{5}{*}{ 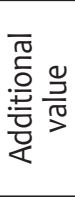 } & V & WV & V & VV & VV & V & VV & V & $\mathrm{V}$ \\
\hline & WV & VV & V & V & VV & VV & VV & VV & WV \\
\hline & V & VV & V & V & V & V & V & VV & VV \\
\hline & V & V & V & V & V & V & VV & VV & V \\
\hline & V & V & GV & V & V & GV & V & V & V \\
\hline
\end{tabular}

$\tilde{w}_{3}=((0.094,0.279,0.784 ; 1),(0.153,0.279,0.526 ; 0.75))$

$\tilde{w}_{4}=((0.161,0.471,1.173 ; 1),(0.232,0.471,0.848 ; 0.75))$

The estimated KPI values (Step 2 of the developed Algorithm) are accounted for in Table 1.

Table 1 The estimated value of the KPIs at the level of each enterprise

Source: Authors 
The aggregated performance values are calculated according to the expression (3) and they are presented in Table 2.

The weighted performance values at the level of each enterprise are calculated according to the expression (5). The multiplication process of the two interval triangular fuzzy type-2 numbers is illustrated by the following example:

$\tilde{\tilde{d}}_{63}=((5.7,7.2,8.4 ; 1),(6.2,7.2 .8 ; 0.6))$.

$\cdot((0.094,0.279,0.784 ; 1),(0.153,0.279,0.526 ; 0.75))=$

$=((0.54,2.01,6.59 ; 1),(0.95,2.01,4.21 ; 0.6))$

The fuzzy decision matrix (Step 4 of the developed Algorithm) is shown in Table 3

The PIS and NIS values are calculated according to the decision matrix (Step 5 of the developed Algorithm) and shown in Table 4.

The values of the approximation coefficient and the rank of the considered enterprises are obtained according to the developed Algorithm (Step 6 to Step 8) and accounted for in Table 7.
Table 4 The decision matrix PIS and NIS

\begin{tabular}{|c|c|c|c|c|}
\hline & $p=1$ & $p=2$ & $p=3$ & $p=4$ \\
\hline$e=1$ & 0.6443 & 0.5827 & 2.3937 & 3.5967 \\
\hline$e=2$ & 0.6153 & 0.6430 & 2.4763 & 4.5957 \\
\hline$e=3$ & 0.7673 & 0.6070 & 2.5593 & 3.4340 \\
\hline$e=4$ & 0.7673 & 0.5713 & 2.3937 & 3.5967 \\
\hline$e=5$ & 0.6443 & 0.4267 & 2.3103 & 3.7187 \\
\hline$e=6$ & 0.7673 & 0.3670 & 2.3103 & 3.5210 \\
\hline$e=7$ & 0.6443 & 0.4267 & 2.3103 & 3.9320 \\
\hline$e=8$ & 0.7673 & 0.3670 & 2.3937 & 4.5957 \\
\hline$e=9$ & 0.7673 & 0.4267 & 2.3937 & 3.7187 \\
\hline PIS & 0.6153 & 0.3670 & 2.5593 & 4.5957 \\
\hline NIS & 0.7673 & 0.6430 & 2.3103 & 3.4340 \\
\hline
\end{tabular}

Source: Authors

Table 2 The aggregated performance values

\begin{tabular}{|c|c|c|c|c|}
\hline & $\mathrm{p}=1$ & $p=2$ & $p=3$ & $p=4$ \\
\hline$e=1$ & $\begin{array}{l}((3.25,4.75,6.25 ; 1), \\
(3.75,4 \cdot 62,5.75 ; 0.6))\end{array}$ & $\begin{array}{l}((1.6,2.8,4 \cdot 3 ; 1) \\
(2,4,2.8,3.8 ; 0.6))\end{array}$ & $\begin{array}{l}((6.5,8,8.75 ; 1), \\
(7,8,8.5 ; 0.6))\end{array}$ & $\begin{array}{l}((5 \cdot 9,7 \cdot 4,8.6 ; 1) \\
(6.4,7 \cdot 4 \cdot 8 ; 0.6))\end{array}$ \\
\hline$e=2$ & $\begin{array}{l}((3,4 \cdot 5,6 ; 1) \\
(3 \cdot 5,4 \cdot 5,5 \cdot 5 ; 0.6))\end{array}$ & $\begin{array}{l}((1.7,3 \cdot 2,4 \cdot 7 ; 1) \\
(2.2,4 \cdot 3 \cdot 2,4 \cdot 2 ; 0.6))\end{array}$ & $\begin{array}{l}((7,8.5,8.87 ; 1), \\
(7.5,8.5,8.75 ; 0.6))\end{array}$ & $\begin{array}{l}((6.7,8.2,8.8 ; 1) \\
(7.2,8.2,8.6 ; 0.6))\end{array}$ \\
\hline$e=3$ & $\begin{array}{l}((4.25,5 \cdot 75,7.25 ; 1) \\
(4 \cdot 75,5 \cdot 75,6.75 ; 0.6))\end{array}$ & $\begin{array}{l}((1.5,3,4 \cdot 5 ; 1) \\
(2,3.8,4 ; 0.6))\end{array}$ & $\begin{array}{l}((7 \cdot 5,9,9 ; 1) \\
(8,9,9 ; 0.6))\end{array}$ & $\begin{array}{l}((5 \cdot 3,6.8,8.3 ; 1), \\
(5.8,6.8 .7 .8 ; 0.6))\end{array}$ \\
\hline$e=4$ & $\begin{array}{l}((4.25,5 \cdot 75,7.25 ; 1) \\
(4.75,5 \cdot 75,6.75 ; 0.6))\end{array}$ & $\begin{array}{l}((1.4,2.6,4 \cdot 4 ; 1) \\
(1.8,2.6,3 \cdot 6 ; 0.6))\end{array}$ & $\begin{array}{l}((6.5,8,8.75 ; 1) \\
(7,8,8.5 ; 0.6))\end{array}$ & $\begin{array}{l}((5 \cdot 9,7 \cdot 4,8.6 ; 1) \\
(6.4,7 \cdot 4 \cdot 8 ; 0.6))\end{array}$ \\
\hline$e=5$ & $\begin{array}{l}((3.25,4 \cdot 75,7.25 ; 1) \\
(3 \cdot 75,4 \cdot 75,5 \cdot 75 ; 0.6))\end{array}$ & $\begin{array}{l}((1.2,1.8,3 \cdot 3 ; 1) \\
(1.4,1.8,2.8 ; 0.6))\end{array}$ & $\begin{array}{l}((6,7.5,8.62 ; 1) \\
(6.5,7 \cdot 5,8.25 ; 0.6))\end{array}$ & $\begin{array}{l}((6.3,7.8,8.7 ; 1) \\
(6.8,7.8 .8 .4 ; 0.6))\end{array}$ \\
\hline$e=6$ & $\begin{array}{l}((4.25,5 \cdot 75,7.25 ; 1), \\
(4 \cdot 75,5 \cdot 75,6.75 ; 0.6))\end{array}$ & $\begin{array}{l}((1.1,1.4,2.9 ; 1) \\
(1.2,1.4,2.4 ; 0.6))\end{array}$ & $\begin{array}{l}((6,7.5,8.62 ; 1) \\
(6.5,7.5,8.25 ; 0.6))\end{array}$ & $\begin{array}{l}((5 \cdot 7,7 \cdot 2,8.4 ; 1), \\
(6.2,7.2 .8 ; 0.6))\end{array}$ \\
\hline$e=7$ & $\begin{array}{l}((3.25,4 \cdot 75,7.25 ; 1), \\
(3.75,4 \cdot 75,5 \cdot 75 ; 0.6))\end{array}$ & $\begin{array}{l}((1.2,1.8,3 \cdot 3 ; 1) \\
(1.4,1.8,2.8 ; 0.6))\end{array}$ & $\begin{array}{l}((6,7.5,8.62 ; 1) \\
(6.5,7 \cdot 5,8.25 ; 0.6))\end{array}$ & $\begin{array}{l}((7.1,8.6,8.9 ; 1) \\
(7.6,8.6 .8 .8 ; 0.6))\end{array}$ \\
\hline$e=8$ & $\begin{array}{l}((4 \cdot 25,5 \cdot 75,7.25 ; 1) \\
(4 \cdot 75,5 \cdot 75,6.75 ; 0.6))\end{array}$ & $\begin{array}{l}((1.1,1 \cdot 4,2 \cdot 9 ; 1) \\
(1.2,1.4, .2 \cdot 4 ; 0.6))\end{array}$ & $\begin{array}{l}((6.5,8,8.75 ; 1) \\
(7,8,8.5 ; 0.6))\end{array}$ & $\begin{array}{l}((6.7,8.2,8.8 ; 1) \\
(7.2,8.2,8.6 ; 0.6))\end{array}$ \\
\hline$e=9$ & $\begin{array}{l}((4.25,5 \cdot 75,7.25 ; 1) \\
(4.75,5 \cdot 75,6.75 ; 0.6))\end{array}$ & $\begin{array}{l}((1.2,1.8,3 \cdot 3 ; 1), \\
(1.4,1.8,2.8 ; 0.6))\end{array}$ & $\begin{array}{l}((6.5,8,8.75 ; 1), \\
(7,8,8.5 ; 0.6)) \\
\end{array}$ & $\begin{array}{l}((6.3,7.8,8.7 ; 1) \\
(6.8,7.8 .8 .4 ; 0.6))\end{array}$ \\
\hline
\end{tabular}


Table 3 The fuzzy decision matrix

\begin{tabular}{|c|c|c|c|c|}
\hline & $p=1$ & $p=2$ & $p=3$ & $p=4$ \\
\hline$e=1$ & $\begin{array}{l}((0.14,0.54,1.95 ; 1) \\
(0.22,0.53,1.31 ; 0.6))\end{array}$ & $\begin{array}{l}((0.1,0.38,2.02 ; 1) \\
(0.19,0.38,1.09 ; 0.6))\end{array}$ & $\begin{array}{l}((0.61,2.23,6.86 ; 1) \\
(1.07,2.23,4.47 ; 0.6))\end{array}$ & $\begin{array}{l}((0.95,3 \cdot 49,10.09 ; 1), \\
(1.48,3 \cdot 49,6.78 ; 0.6))\end{array}$ \\
\hline$e=2$ & $\begin{array}{l}((0.13,0.51,1.87 ; 1) \\
(0.21,0.51,1.25 ; 0.6))\end{array}$ & $\begin{array}{l}((0.11,0.44,2.21 ; 1) \\
(0.18,0.44,1.21 ; 0.6))\end{array}$ & $\begin{array}{l}((0.66,2.37,6.95 ; 1) \\
(1.15,2 \cdot 37,4.61 ; 0.6))\end{array}$ & $\begin{array}{l}((1.08,3.86,15 \cdot 23 ; 1) \\
(1.67,3 \cdot 38,7.29 ; 0.6))\end{array}$ \\
\hline$e=3$ & $\begin{array}{l}((0.19,0.66,2.26 ; 1), \\
(0.29,0.66,1.54 ; 0.6))\end{array}$ & $\begin{array}{l}((0.09,0.41,2.11 ; 1) \\
(0.16,0.41,1.15 ; 0.6))\end{array}$ & $\begin{array}{l}((0.71,2.51,7.06 ; 1) \\
(1.22,2 \cdot 51,4.73 ; 0.6))\end{array}$ & $\begin{array}{l}((0.85,3 \cdot 21,9.74 ; 1) \\
(1.35,3 \cdot 21,6.78 ; 0.6))\end{array}$ \\
\hline$e=4$ & $\begin{array}{l}((0.19,0.66,2.26 ; 1), \\
(0.29,0.66,1.54 ; 0.6))\end{array}$ & $\begin{array}{l}((0.09,0.35,2.07 ; 1) \\
(0.15,0.35,1.03 ; 0.6))\end{array}$ & $\begin{array}{l}((0.61,2.23,6.86 ; 1) \\
(1.07,2.23,4.47 ; 0.6))\end{array}$ & $\begin{array}{l}((0.95,3 \cdot 49,10.09 ; 1), \\
(1.48,3 \cdot 49,6.78 ; 0.6))\end{array}$ \\
\hline$e=5$ & $\begin{array}{l}((0.14,0.54,2.26 ; 1) \\
(0.23,0.54,1.31 ; 0.6))\end{array}$ & $\begin{array}{l}((0.08,0.24,1.55 ; 1) \\
(0.11,0.24,0.8 ; 0.6))\end{array}$ & $\begin{array}{l}((0.56,2.09,6.76 ; 1) \\
(0.99,2.09,4.34 ; 0.6))\end{array}$ & $\begin{array}{l}((1.01,3 \cdot 67,10.21 ; 1) \\
(1.58,3 \cdot 67,7 \cdot 12 ; 0.6))\end{array}$ \\
\hline$e=6$ & $\begin{array}{l}((0.19,0.66,2.26 ; 1) \\
(0.29,0.66,1.54 ; 0.6))\end{array}$ & $\begin{array}{l}((0.07,0.19,1.36 ; 1) \\
(0.09,0.19, .0 .69 ; 0.6))\end{array}$ & $\begin{array}{l}((0.56,2.09,6.76 ; 1) \\
(0.99,2.09,4.34 ; 0.6))\end{array}$ & $\begin{array}{l}((0.92,3 \cdot 39,9.85 ; 1) \\
(1.44,3 \cdot 39,6.78 ; 0.6))\end{array}$ \\
\hline$e=7$ & $\begin{array}{l}((0.14,0.54,2.26 ; 1) \\
(0.23,0.54,1.31 ; 0.6))\end{array}$ & $\begin{array}{l}((0.08,0.24,1.55 ; 1) \\
(0.11,0.24,0.8 ; 0.6))\end{array}$ & $\begin{array}{l}((0.56,2.09,6.76 ; 1), \\
(0.99,2.09,4.34 ; 0.6))\end{array}$ & $\begin{array}{l}((1.14,4.05,10.44 ; 1) \\
(1.76,4.05,7.46 ; 0.6))\end{array}$ \\
\hline$e=8$ & $\begin{array}{l}((0.19,0.66,2.26 ; 1) \\
(0.29,0.66,1.54 ; 0.6))\end{array}$ & $\begin{array}{l}((0.07,0.19,1.36 ; 1) \\
(0.09,0.19, .0 .69 ; 0.6))\end{array}$ & $\begin{array}{l}((0.61,2.23,6.86 ; 1) \\
(1.07,2.23,4.47 ; 0.6))\end{array}$ & $\begin{array}{l}((1.08,3 \cdot 86,15 \cdot 23 ; 1) \\
(1.67,3 \cdot 38,7.29 ; 0.6))\end{array}$ \\
\hline$e=9$ & $\begin{array}{l}((0.19,0.66,2.26 ; 1), \\
(0.29,0.66,1.54 ; 0.6))\end{array}$ & $\begin{array}{l}((0.08,0.24,1.55 ; 1), \\
(0.11,0.24,0.8 ; 0.6))\end{array}$ & $\begin{array}{l}((0.61,2.23,6.86 ; 1) \\
(1.07,2.23,4.47 ; 0.6))\end{array}$ & $\begin{array}{l}((1.01,3 \cdot 67,10.21 ; 1) \\
(1.58,3.67,7.12 ; 0.6))\end{array}$ \\
\hline
\end{tabular}

Source: Authors

Table 5 The values of the approximation coefficient and the rank of the enterprises

\begin{tabular}{c|cccc}
\hline \multicolumn{2}{c}{$y_{\mathrm{p}}^{+}$} & $\mathrm{y}_{\bar{p}}$ & $\mathrm{k}_{\mathrm{e}}$ & Rang \\
\hline $\mathrm{e}=1$ & 1.0356 & 0.2285 & 0.1103 & 9 \\
$\mathrm{e}=2$ & 0.2882 & 1.1833 & 0.8041 & 2 \\
$\mathrm{e}=3$ & 1.1959 & 0.2516 & 0.5000 & 3 \\
$\mathrm{e}=4$ & 1.0442 & 0.1964 & 0.1583 & 8 \\
$\mathrm{e}=5$ & 0.9141 & 0.3781 & 0.2714 & 6 \\
$\mathrm{e}=6$ & 1.1136 & 0.2894 & 0.2063 & 7 \\
$\mathrm{e}=7$ & 0.7119 & 0.5487 & 0.4353 & 4 \\
$\mathrm{e}=8$ & 0.2248 & 1.1970 & 0.8419 & 1 \\
$\mathrm{e}=9$ & 0.9073 & 0.3671 & 0.2880 & 5 \\
\hline
\end{tabular}

Source: Authors

\section{DISCUSSION ON RESULTS}

Respecting the results presented in Table 7, it can be concluded that the enterprises $(\mathrm{e}=8)$ and $(\mathrm{e}=2)$ are the most efficient in the considered LS because they are ranked the first and the second, respectively. The enterprise $(e=1)$ is ranked the last. Since the closeness coefficient value of the enterprise $(\mathrm{e}=1)$ is almost equal to the closeness coefficient value of the enterprise $(e=4)$ and the enterprise $(e=6)$, it can be said that the management should simultaneously undertake appropriate measures for improving the performance of the enterprises $(e=1, e=4$ and $e=6)$, which are ranked the last, the $8^{\text {th }}$ and the $7^{\text {th }}$. In all of the three enterprises, the quality performance $(p=3)$ values and added value $(p=4)$ have the smallest weighted values. Hence, it can be concluded that it is necessary for the management team to take the first steps that should lead to the improvement of these performances. Improving the quality of the performance $(p=3)$ can be achieved through the improvement of the supply strategy, the introduction of new leadership concepts, 
etc. The improvement of the supply strategy can be realized through the realization of a partnership relationship with the suppliers of repro materials, the introduction of the information systems that may improve communication between all the entities in the $\mathrm{SC}$, the use of inventory management and production systems, etc. An increase in the added value $(p=4)$ of the enterprises $(e=1, e=4$, and $e=6)$ can be achieved by using the lean principle, such as the pull system.

The weighted complexity performance value ( $p$ $=1)$ in the enterprises $(e=4)$ and $(e=6)$ is higher than the value of the same performance in the enterprise that is the 1st ranked $(e=8)$. Therefore, the management team should take appropriate measures to reduce complexity in the enterprises ( $\mathrm{e}=$ 4) and $(e=6)$. Complexity reduction can be realized through the improvement of the value-stream map. By determining the value-stream map, it is possible to see all the unnecessary subprocesses and activities of the production process. Their elimination reduces the complexity of the enterprise. The complexity of the SC can also be reduced by applying the method of reengineering processes and products.

\section{CONCLUSION}

The management and improvement of SC performances represents one of the most important management tasks. A solution to this problem should lead to the enhancement of the competitiveness and sustainability of the SC over a longer period of time. By simultaneously improving the performances of all of the SC entities, the effectiveness of the SC will surely increase. Also, if this scenario is applied, there is a great deal of resource usage (time, money, etc.). In order to achieve the enhancement of the effectiveness of the SC, with the least possible use of resources, it is necessary to identify the SC enterprises whose performance needs to be improved. It has been demonstrated that the use of the analytical methods in the evaluation and ranking of enterprises generates more accurate results than the use of intuitive decision-making methods does.
The main contribution of this paper is the development of the model for the evaluation and ranking of the enterprises integrated in the SC respecting the performance of the SC, as well as their weights. Since the SC exists in a rapidly changing environment, the relative importance of the performances and their values are described by the interval triangular fuzzy numbers of the type-2. It can be assumed that this approach in the modeling of uncertain and imprecise data is quite appropriate when there is not enough information about the nature of uncertainties. It has been shown that the ranking of enterprises can be posed as a multiple-criteria decision-making problem. Based on the obtained rank of enterprises, the priority of the enterprises in which performance improvement is to be performed is determined. The priority of the measures in the considered enterprises is determined by comparing the current and the target performance values.

The proposed model was tested on the real data obtained from the automotive industry SC that exists in Central Serbia. This paper makes a contribution to both the theoretical and the practical domains. The modeling of uncertainties and the modifications of the conventional TOPSIS method represent the basic contributions to the theoretical domain. The developed model is flexible in terms of changing the number of performances, their importance and values, and therefore can be applied to solve similar problems that exist in different industrial branches. In the practical domain, the contribution of this work can be identified as a reduction in the resources that need to be spent in order to improve the businesses effectiveness of the enterprises integrated in the SC.

The main limitation of the model is the non-existence of a unique SC performance classification.

Future research should include the development and application of exact methods for determining the improvements of optimal performances. The developed model can also be applied to the SCs of different industrial branches. 


\section{REFERENCES}

Anitha, J. (2014). Determinants of employee engagement and their impact on employee performance. International journal of productivity and performance management, 63(3), 308-323. doi.org/10.1108/IJPPM-01-2013-0008

Baas, S. M., \& Kwakernaak, H. (1977). Rating and ranking of multiple-aspect alternatives using fuzzy sets. Automatica, 13(1), 47-58. doi.org/10.1016/0005-1098(77)90008-5

Beamon, B. M. (1999). Measuring supply chain performance. International journal of operations \& production management, 19(3), 275-292. doi.org/10.1108/01443579910249714

Behery, M., Jabeen, F., \& Parakandi, M. (2014). Adopting a contemporary management system: A fast-growth smallto-medium enterprise (FGSME) in the UAE. International Journal of Productivity and Performance Management, 63(1), 22-43. doi.org/10.1108/IJPPM-07-2012-0076

Bezuidenhout, C. N., Bodhanya, S., Sanjika, T., Sibomana, M., \& Boote, G. L. N. (2012). Network-analysis approaches to deal with causal complexity in a supply network. International Journal of Production Research, 50(7), 18401849. doi.org/10.1080/00207543.2011.575088

Bolstorff, P., \& Rosenbaum, R. (2003). Supply chain excellence. New York, NY: American Management Association.

Castillo, O., \& Melin, P. (2012). Recent advances in interval Type-2 fuzzy systems. (Vol. 1), New York, NY: Springer Science \& Business Media.

Chang, D. Y. (1996). Applications of the extent analysis method on fuzzy AHP. European journal of operational research, 95(3), 649-655. doi.org/10.1016/03772217(95)00300-2

Chen, S. M., \& Lee, L. W. (2010). Fuzzy multiple attributes group decision-making based on the interval type-2 TOPSIS method. Expert systems with applications, 37(4), 2790-2798. doi.org/10.1016/j.eswa.2009.09.012

Cheng, C. Y., Chen, T. L., \& Chen, Y. Y. (2014). An analysis of the structural complexity of supply chain networks. Applied Mathematical Modelling, 38(9-10), 2328-2344. doi. org/10.1016/j.apm.2013.10.016

Cocca, P., \& Alberti, M. (2010). A framework to assess performance measurement systems in SMEs. International Journal of Productivity and Performance Management, 59(2), 186-200. doi.org/10.1108/17410401011014258
Dubois, D., \& Prade, H. (1980). Fuzzy sets and systems. New York, NY: Academic Press.

Feili, H. R., Farahani, N. V., \& Vesaghi, N. (2011). Integration of fuzzy analytic hierarchy process (FAHP) with balance score card (BSC) in order to evaluate the performance of information technology in industry. The Journal of Mathematics and Computer Science, 2(2), 271-283.

Felfel, H., Ayadi, O., \& Masmoudi, F. (2016). Multiobjective stochastic multi-site supply chain planning under demand uncertainty considering downside risk. Computers \& Industrial Engineering, 102, 268-279. doi. org/10.1016/j.cie.2016.10.025

Frohlich, M. T., \& Westbrook, R. (2002). Demand chain management in manufacturing and services: Webbased integration, drivers and performance. Journal of Operations Management, 20(6), 729-745. doi.org/10.1016/ S0272-6963(02)00037-2

Hakimollahi, M., Naini, S. J., Bagherpour, M., Jafari, S., \& Shahmoradi, A. (2012). Balanced scorecard with fuzzy inference as a performance measurement in an automotive manufacturing line. International Journal of Automotive Engineering, 2(4), 276-283.

Kahraman, C., Öztayşi, B., Sarı, İ. U., \& Turanoğlu, E. (2014). Fuzzy analytic hierarchy process with interval type-2 fuzzy sets. Knowledge-Based Systems, 59, 48-57. doi. org/10.1016/j.knosys.2014.02.001

Kaplan, S. R., \& Norton, P. D. (2008). The execution premium: Linking strategy to operations for competitive advantages. Boston, USA: Harvard Business School Publishing Corporation.

Kuei, C. H., \& Madu, C. N. (2001). Identifying critical success factors for supply chain quality management (SCQM). Asia Pacific Management Review, 6(4), 409-423.

Kupers, R. (2000). What organizational leaders should know about the new science of complexity. Complexity, 6(1), 14-19. doi:10.1002/1099-0526(200009/10)6:1<14::aidcplx1002>3.0.c0;2-6

Lootsma, F. (1997). Fuzzy logic for planning and decision making. New York, NY: Springer. doi:10.1007/978-1-47572618-3 
Maiti, T., \& Giri, B. C. (2017). Two-period pricing and decision strategies in a two-echelon supply chain under price-dependent demand. Applied Mathematical Modelling, 42, 655-674. doi.org/10.1016/j.apm.2016.10.051

Mendel, J. M., \& Liu, F. (2007). Super-exponential convergence of the Karnik-Mendel algorithms for computing the centroid of an interval type-2 fuzzy set. IEEE Transactions on Fuzzy Systems, 15(2), 309-320. doi:10.1109/tfuzz.2006.882463

Merigó, J. M., \& Casanovas, M. (2008). Using fuzzy numbers in heavy aggregation operators. International Journal of Information Technology, 4(3), 177-182.

Neely, A. D., Gregory, M., \& Platts, K. (1995). Performance measurement system design: A literature review and research agenda. International Journal of Operations \& Production Management, 15(4), 80-116. doi. org/10.1108/01443579510083622

Nestic, S., Djordjevic, A., Puskaric, H., Zahar Djordjevic, M., Tadic, D., \& Stefanovic, M. (2015). The evaluation and improvement of process quality by using the fuzzy sets theory and genetic algorithm approach. Journal of Intelligent and Fuzzy Systems, 29(5), 2017-2028. doi:10.3233/ ifs-151679

Pal, P., \& Kumar, B. (2008). "16T": Toward a dynamic vendor evaluation model in integrated SCM processes. Supply Chain Management: An International Journal, 13(6), 391-397. doi.org/10.1108/13598540810905642

Pathak, S. D., Day, J. M., Nair, A., Sawaya, W. J., \& Kristal, M. M. (2007). Complexity and adaptivity in supply networks: Building supply network theory using a complex adaptive systems perspective. Decision sciences, 38(4), 547-580. doi:10.1111/j.1540-5915.2007.00170.x

Pawlak, Z. (1998). Rough set theory and its applications to data analysis. Cybernetics \& Systems, 29(7), 661-688. doi. org/10.1080/019697298125470

Presutti, W. D. (2003). Supply management and e-procurement: Creating value added in the supply chain. Industrial marketing management, 32(3), 219-226. doi. org/10.1016/S0019-8501(02)00265-1
Ramesh, V., \& Kodali, R. (2012). A decision framework for maximising lean manufacturing performance. International Journal of Production Research, 50(8), 22342251. doi.org/10.1080/00207543.2011.564665

Saaty, T. L. (1990). How to make a decision: The analytic hierarchy process. European journal of operational research, 48(1), 9-26. doi.org/10.1016/0377-2217(90)90057-I

Sadikoglu, E., \& Zehir, C. (2010). Investigating the effects of innovation and employee performance on the relationship between total quality management practices and firm performance: An empirical study of Turkish firms. International journal of production economics, 127(1), 13-26. doi.org/10.1016/j.ijpe.2010.02.013

Saranga, H., \& Moser, R. (2010). Performance evaluation of purchasing and supply management using value chain DEA approach. European Journal of Operational Research, 207(1), 197-205. doi.org/10.1016/j.ejor.2010.04.023

Shih, H. S., Shyur, H. J., \& Lee, E. S. (2007). An extension of TOPSIS for group decision making. Mathematical and Computer Modelling, 45(7), 801-813. doi.org/10.1016/j. mcm.2006.03.023

Tadic, D., Aleksic, A., Mimovic, P., Puskaric, H., \& Misita, M. (2016). A model for evaluation of customer satisfaction with banking service quality in an uncertain environment. Total Quality Management \& Business Excellence, 1-20. doi.org/10.1080/14783363.2016.1257905

Tadić, D., Đorđević, A., Erić, M., Stefanović, M., \& Nestić, S. (2017). Two-step model for performance evaluation and improvement of New Service Development process based on fuzzy logics and genetic algorithm. Journal of Intelligent and Fuzzy Systems, 33(6), 3959-3970. doi:10.3233/ jifs-17802

Wong, C. Y., \& Boon-itt, S. (2008). The influence of institutional norms and environmental uncertainty on supply chain integration in the Thai automotive industry. International Journal of Production Economics, 115(2), 400-410. doi.org/10.1016/j.ijpe.2008.05.012

Xu, L., Li, Y., Govindan, K., \& Xu, X. (2015). Consumer returns policies with endogenous deadline and supply chain coordination. European Journal of Operational Research, 242(1), 88-99. doi.org/10.1016/j.ejor.2014.09.049 
Yoon, K., \& Hwang, C. L. (1981). Multiple attribute decision making: Methods and applications. Berlin, BRD: SpringerVerlag Berlin An. doi:10.1007/978-3-642-48318-9

Zadeh, L. (1975). The concept of a linguistic variable and its application to approximate reasoning. Information Sciences, 8(4), 301-357. doi.org/10.1016/0020-0255(75)90046-8

Zhai, L. Y., Khoo, L. P., \& Zhong, Z. W. (2009). Design concept evaluation in product development using rough sets and grey relation analysis. Expert Systems with Applications, 36(3), 7072-7079. doi.org/10.1016/j.eswa.2008.08.068
Zhang, Z., \& Zhang, S. (2017). Comments on "A note on "A novel approach to multi attribute group decision making based on trapezoidal interval type-2 fuzzy soft sets'"'. Applied Mathematical Modelling, 41, 702-710. doi. org/10.1016/j.apm.2016.09.011

Zimmermann, H. (2001). Fuzzy Sets Theory - And Its Applications. Amsterdam, Netherlands: Springer-Verlag. doi:10.1007/978-94-010-0646-0

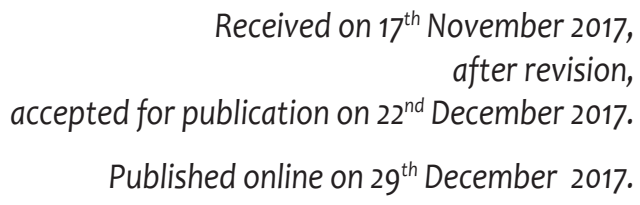

Danijela Tadic is a Professor at the Faculty of Engineering, University of Kragujevac, Kragujevac, the Republic of Serbia. She obtained her PhD degree at the Faculty of mechanical engineering, University of Belgrade. Her field of research includes operational research and supply chain management.

Aleksandar Djordjevic is a Research Associate at the Faculty of Engineering, University of Kragujevac, Kragujevac, the Republic of Serbia, where he received his PhD degree. His field of research includes operational research and information management. 


\title{
MODEL ZA UPRAVLJANJE LANCEM SNABDEVANJA ZASNOVAN NA INTERVALNIM FAZI BROJEVIMA TIPA-2 I TOPSIS METODI
}

\author{
Danijela Tadić* i Aleksandar Đorđević \\ Fakultet inženjerskih nauka Univerziteta u Kragujevcu
}

Poboljšanje performansi lanca snabdevanja rezultira povećavanjem efektivnosti poslovanja preduzeća integrisanih u lanac snabdevanja i celog lanca snabdevana. Rešenje problema unapređivanja performansi lanca snabdevanja može se dobiti merenjem i poboljšanjem odnosnih performansi, što predstavlja osnovnu svrhu ovog istraživanja. Relativnu važnost performansi i vrednosti njihovih ključnih indikatora procenjuju donosioci odluka. Njihove procene su opisane lingvističkim variablama, koje su modelirane intervalnim fazi brojevima tipa-2. Relativna važnost performansi je zadata pomoću fazi matrice relativne važnosti svakog para performansi. Ponderi performansi su izračunati pomoću metode sopstvenog vektora. Vrednosti performansi su računate primenom operatora fazi srednje vrednosti. Rang preduzeća sa respektovanjem svih razmatranih performansi i njihova težina su određeni konvencionalnom TOPSIS metodom. Rangiranje preduzeća koja su integrisana u lanac snabevanja može da se označi kao glavni rezultat istraživanja. Na osnovu dobijenog ranga mogu da se preduzmu odgovarajuće mere za poboljšanje performansi onih preduzeća koja su najlošije ocenjena shodno posmatranim performansama. Predloženi model je testiran na primeru lanca snabdevanja automobilske industrije u Centralnoj Srbiji.

Ključne reči: performanse lanca snabdevanja, intervalni fazi brojevi tipa-2, fazi AHP, TOPSIS, menadžment mere

JEL Classification: C69, L62

\section{UVOD}

Upravljanje lancem snabdevanja (LS) predstavlja jedan od najvažnijih problema kako $\mathrm{u}$ istraživačkom, tako i u domenu prakse. Razmatrani problem je složen i sastoji se od većeg broja potproblema. Jedan od

* Korespondencija: D. Tadić, Fakultet inženjerskih nauka, Univerzitet u Kragujevcu, Sestre Janjić 6, 34000 Kragujevac, Republika Srbija; e-mail: galovic@kg.ac.rs potproblema, koji ima kritičan uticaj na efektivnost i konkurensku prednost LS, je merenje i kontinualno poboljšanje performansi LS. Ovaj problem je posebno važan za LS auto industrije, koji doprinose održivom ekonomskom razvoju svake države, a posebno država u razvoju. Automobilska industrija može se posmatrati kao potencijalni stimulans za preduzetništvo pomoću kreiranja novih tržišta i razvoja mnogobrojnih poslova za koje su potrebna veća znanja i veštine. Drugim 
rečima, povećanje efektivnosti i efikasnosti poslovanja LS $\mathrm{u}$ auto indistriji dovodi do razvoja regiona u kojem egzistira LS kao i cele države.

Predmet istraživanja $u$ ovom radu jeste ocena i rangiranje preduzeća koja su uključena u LS, respektujući performanse LS. Ocena performansi LS i njihovih Ključnih Indikatora Performansi (KPI) može da se dobije na osnovu procene donosioca odluka. Oni svoje procene zasnivaju na znanju, iskustvu, podacima iz evidencije. Donosioci odluke koriste lingvističke iskaze pomoću kojih opisuju vrednosti egzistirajućih neizvesnosti. Poznato je da je donosiocima odluke lakše da svoja znanja i iskustva iskazuju prirodnim jezikom, nego da ga preslikavaju na neku skalu mera. Koncept lingvističke varijable je uveo L. Zadeh (1975), i definisao je kao varijablu čije su vrednosti reči, a ne brojevi. Modeliranje lingvističkih varijabli može da bude izvršeno primenom različitih teorija, kao, na primer, teorije verovatnoće, teorije fazi skupova (Zimmerman, 2001), i teorije grubih skupova (Pawlak, 1998). Modeliranje neizvesnih podataka pomoću slučajne promenljive zahteva veliki broj releventnih podatata iz evidencije. Usled brze i neprekidne promene okruženja, gotovo je nemoguće obezbediti dovoljan broj tačnih podataka. Teorija grubih skupova (Pawlak, 1998) može efikasno da se koristi za analizu neizvesnih i nekompletnih informacija, koje su modelovane zatvorenim intervalom. Ovo može da se označi kao glavna prednost teorije grubih skupova u odnosu na teoriju fazi skupova (Zimmerman, 2001), kod koje su neizvesnosti opisane funkcijom raspodele mogućnosti. Mada iz poređenja teorije grubih skupova i teorije fazi skupova proizilazi da teorija fazi skupova ima prednosti u modelovanju nepreciznih i nejasnih podataka (Zhai, Khoo \& Zhong, 2009). U ovom radu, sve neizvesnosti su modelirane pomoću intervalnih trougaonih fazi brojeva tipa-2, koji predstavljaju specijalan slučaj generalizovanih tipa-2 fazi skupova. Treba naglasiti da generalizovani fazi skupovi tipa-2 zahtevaju složena matematička izračunavanja, i, stoga, nemaju veliku primenu u opisivanju i modeliranju neizvesnosti u realnim problemima.
Osnovni cilj istraživanja je rangiranje preduzeća unutar lanca snabdevanja, a izvedeni ciljevi su identifikovanje performansi LS i njihovih KPI, modeliranje neizvesnosti $\mathrm{u}$ relativnoj važnosti performansi i vrednosti njihovih KPI pomoću intervalnih trougaonih fazi brojeva tipa-2 (Chen \& Lee, 2010; Kahraman, Öztayşi, Sarı \& Turanoğlu, 2014; Zhang \& Zhang, 2017), određivanje težine performansi primenom relativne važnosti performansi, određivanje ranga preduzeća koja $\mathrm{su}$ integrisana $\mathrm{u}$ LS primenom TOPSIS metode, i preduzimanje odgovarajućih menadžment inicijativa u cilju poboljšanja performansi preduzeća, čime se utiče na povećanje efektivnosti poslovanja LS i njegove konkurentske prednosti.

Osnovna hipoteza glasi:

$\mathrm{H}_{0}$ : Prioritet mera koje treba da dovedu do poboljšanja performansi preduzeća integrisanih u LS može biti zasnovan na rangu razmatranih preduzeća.

U literaturi se može naći niz metoda za merenje i unapređenje performansi preduzeća $u$ kojima se realizuju različite privredne delatnosti. Međutim, gotovo da nema radova $u$ kojima se razmatra problem ocenjivanja preduzeća povezanih u LS sa respektovanjem performansi LS.

Motivacija za ovaj rad potiče iz pretpostavke da primenom egzaktnih metoda za ocenjivanje preduzeća intergisanih $\mathrm{u}$ LS mogu da se dobiju precizniji rezultati na osnovu kojih se definišu mere unapređenja poslovanja LS.

Rad je organizovan na sledeći način. Kratak pregled relevantne literature je prikazan u Sekciji 2. Prikaz performansi LS i njihovih KPI je prikazan u Sekciji 3. Modeliranje neizvesnosti i predloženi algoritam su prikazani u četvrtoj sekciji. Predložena procedura je ilustrovana na podacima dobijenim u LS auto industrije $\mathrm{u}$ realnom okruženju. Zaključci su prezentovani $\mathrm{u}$ Sekciji 5. 


\section{PREGLED LITERATURE}

Upravljanje LS je zasnovano na određivanju, merenju i poboljšanju performansi LS i njegovih KPI. A. D. Neely, M. Gregory i K. Platts (1995) sugerišu da kontinualno praćenje vrednosti performansi i preduzimanje mera zasnovanih na dobijenim vrednostima performansi može da dovede do povećanja efektivnosti i efikasnosti upravljanja LS.

U tradicionalnom pristupu upravljanja LS, menadžment tim se fokusirao na jednu performansu, najčešće troškove. Merenjem i poboljšanjem jedne performance LS nije moguće da se ostvari poboljšanje svih, ili makar većine strategijskih ciljeva, koji su definisani na nivou LS. U literaturi postoje mnogobrojni pristupi predloženi za rešavanje problema određivanja perfomansi LS i njegovih KPI. Neki autori smatraju da određivanje performansi bilo kog organizacionog sistema, pa tako i LS, može da bude zasnovano na rezultatima najbolje prakse (Coccoa \& Alberti, 2010). J. Anitha (2014) smatra da identifikovanje performansi treba da bude zasnovano na analizi podataka koji su dobijeni anketom. Validnost rezultata (u ovom slučaju to je skup performansi LS) može da se potvrdi primenom regresione analize. B. M. Beamon (1999) je sve performance LS grupisao u tri grupe: performance resursa, izlaza, i fleksibilnosti. Respektujući zahteve ISO 9001:2008, kao i rezultate dobre prakse (Nestic, Djordjevic, Puskaric, Zahar Djordjevic, Tadic, \& Stefanovic, 2015; Tadić, Đorđević, Erić, Stefanović, \& Nestić, 2017), definisane su performanse proizvodnih LS. U radu V. Ramesh-a i R. Kodali-a (2012) sumirani su rezultati iz brojnih izvora, i predložena lista performansi za lean proizvodni LS. U ovom radu performanse LS su određene prema preporukama koje su definisane u Supply-Chain Operations Reference - SCOR modelu (Bolstorff \& Rosenbaum, 2003), i one su opisane u Sekciji 3.

Vrednosti performansi mogu se dobiti merenjem, ili na osnovu procene donosilaca odluke. Donosioci odluka mogu da koriste unapred definisane skale mera pomoću kojih svoje stavove preslikavaju na skup realnih brojeva. U literaturi se koriste mnogobrojne skale mera, kao, na primer, standardna skala mera (Coccoa \& Alberti, 2010). Preslikavanje procena na skup lingvističkih iskaza umesto na skup preciznih brojeva je daleko bliže ljudskom načinu razmišljanja pa je samim tim i tačnije. Imajući ovu činjenicu u vidu, mnogi autori sugerišu korišćenje lingvističkih iskaza za opisivanje vrednosti performansi (Nestić et al, 2015). Modeliranje lingvističkih iskaza (Nestić et al, 2015; Tadić et al, 2017) zasnovano je na teoriji fazi skupova (Dubois \& Prade, 1980; Zimmermann, 2001). Odnosno, ovi lingvistički iskazi su modelirani trougaonim fazi brojevima. Zadatak procene relativne važnosti svake performance je postavljen kao problem fazi grupnog odlučivanja (Nestić et al, 2015). Agregirana vrednost procena donosioca odluka je dobijena primenom fazi ponderisanog operatora agregacije (FOWA), koji se široko koristi u literaturi (Merigó \& Casanovas, 2008). Ukupna vrednost svake performance se računa kao proizvod relativne važnosti i procenjene vrednosti, i opisana je trougaonim fazi brojem na osnovu pravila fazi algebre (Dubois and Prade, 1980).

Mnogobrojne metode za merenje performansi koje su razvijene na različitim matematičkim i logičkim okvirima mogu da se nađu u literaturi. Ove metode su razvijene za merenje performansi organizacionih sistema koji se međusobno razlikuju po veličini i po privrednoj grani kojoj pripadaju, načinu povezanosti i dr.

Najšire korišćena metoda za merenje performansi $u$ preduzećima u kojima se realizuju različite privredne delatnostije pristup uravnoteženih pokazatelja (Balanced Scorecard - BSC) (Kaplan \& Norton, 2008). Primenom ove metode određuju se vrednosti performansi na različitim perspektivama. Na ovaj način, moguće je uspostaviti ravnotežu između dugoročnih i kratkoročnih ciljeva, i između finansijskih i nefinansijskih performansi. Pomoću BSC pristupa moguće je da se strategijski ciljevi transformišu u skup performansi. Neophodna je primena BSC pristupa na svim nivoima upravljanja, kako bi se ostvarili bolji rezultati merenja performansi (Behery, Jabeen, \& Parakandi, 2014). Na ovaj način, postavljanje ciljeva, određivanje prioriteta mera za postizanje ciljeva, i alokacija resursa su značajno jednostavniji, u poređenju sa ostalim tehnikama za merenje performansi. Primenom BSC pristupa, 
pojednostavljeno je unapređivanje formulisane strategije upravljanja.

M. Hakimollahi, S. J. Naini, M. Bagherpour, S. Jafari i A. Shahmoradi (2012) su razvili metodu za merenje performansi koja je zasnovana na BSC sa fazi interferentnim mehanizmom. Vrednosti KPI performansi koje su definisane na svakoj BSC perspektivi su određene primenom fazi ako-onda pravila. Procena eksperata o vrednostima KPI-ova je određena na osnovu znanja i iskustva donosilaca odluka. Rang KPI na nivou svih razmatranih procesa, respektujući istovremeno sva preduzeća, dobijen je primenom metode poređenja kontinualnih fazi brojeva (Baas \& Kwakernaak, 1977; Dubosi \& Prade, 1980; Nestić et al, 2015).

Mnogi autori sugerišu da određivanje vrednosti performansi može da se definiše kao zadatak višeatributivnog odlučivanja (Saranga and Moser, 2010; Feili, Farahani, \& Vesaghi, 2011). Ocene relativne važnosti KPI-ova na nivou svake performance i njihove vrednosti su dobijene primenom ankete u kojoj su učestvovali donosioci odluka, koji potiču iz različitih preduzeća koja pripadaju istoj industrijskoj grani (Feili et al, 2011). Donosioci odluke su odgovarali na pitanja definisana $\mathrm{u}$ anketi tako što su koristili unapred definisane lingvističke iskaze koji su modeliranim trougaonim fazi brojevima. Agregrirana vrednost procena donosilaca odluka je računata kao geometrijska sredina procena koje potiču od svih eksperata koji učestvuju u anketi. Ponderisane agregirane vrednosti KPI unutar svake performance računaju se kao proizvod pondera i procenjene vrednosti. Prioritet KPI na nivou svake performanse je dobijen primenom fazi Analitičkog Hijerarhijskog Procesa (AHP) (Chang, 1996). H. Saranga i R. Moser (2010) sugerišu korišćenje Data Envelopment Analyses - DEA metode za određivanje vrednosti performansi. Neizvesnosti u relativnim važnostima performansi i njihovim vrednostima su opisane lingvističkim iskazima koji su modelirani trougaonim fazi brojevima (Tadić et al, 2017). Postavljena je fazi matrica parova upoređenja relativnih važnosti performansi. Obrada neizvesnosti je izvršena primenom metode proširene analize (Chang,
1996). Normalizovane vrednosti performansi su dobijene primenom procedure linearne normalizacije (Shih, Shyur \& Lee, 2007). Elementi ponderisane normalizovane fazi matrice odlučivanja se računaju kao proizvod izračunatog pondera i procenjene vrednosti performansi. Fazi pozitivno idealno rešenje i fazi negativno idealno rešenje, i koeficijenti približavanja na osnovu kojih se određuje rang performansi se računaju kao kod konvencionalne Technique for Order Preference by Similarity to Ideal Solution - TOPSIS (Yoon \& Hwang, 1981).

Prema zahtevima standarda ISO 9001:2015 neophodno je vršiti stalna unapređenja poslovnih procesa. To se, između ostalog, postiže poboljšavanjem vrednosti performansi procesa. Na ovaj način, postavljeni ciljevi mogu biti u potpunosti realizovani. Poboljšanje performansi se postiže primenom odgovarajućih menadžment mera koje su definisane u standardu, procedurama sistema kvaliteta koji je uveden $u$ preduzeće, ili mogu da ih definišu donosioci odluke na osnovu svojih znanja i iskustava. U radovima koji su analizirani u ovoj sekciji, prioritet mera korespondira prioritetu preduzeća koja su integrisana u LS.

Poređenjem predloženog modela sa modelima koji su razvijeni i prikazani u ovom radu mogu da se uoče relevantne razlike. Na osnovu dobijenih rezultata, može se uočiti prednost modela koji je razvijen u ovom radu.

Određivanje performansi je zadatak koji ima veliku važnost, jer utiče na ceo proces odlučivanja. U radu su performance LS određene na osnovu P. Bolstorff -og i R. Rosenbaum-ovog pristupa (2003). Može se smatrati da je lista performansi bolje definisana, nego kada se koriste neke druge metode (Coccoa \& Alberti, 2010; Anitha, 2014; Nestić et al, 2015).

Relativne važnosti KPI i njihove vrednosti su procenje od strane donosioca odluka koji koriste unapred definisane lingvističke iskaze (Feili et al, 2011; Nestić et al, 2015). Korišćenje lingvističkih variabli dopušta donosiocima odluka da bolje iskažu svoje procene, nego korišćenje skala mera (Kaplan \& Norton, 2008; Coccoa \& Alberti, 2010). Neizvesnosti u relativnim važnostima performansi ili KPI, kao i njihovim vrednostima su 
opisane intervalnim tipa-2 fazi brojevima (Chen \& Lee, 2010; Kahraman et al, 2014; Zhang \& Zhang, 2017). Smatra se da intervalni tipa-2 fazi brojevi mogu bolje da opišu neizvestan i neprecizan podatak (Chen \& Lee, 2010), i kada nije moguće da se na egzaktan način odredi oblik funkcije raspodele mogućnosti tipa-1 fazi broja (Castillo \& Melin, 2012). Polazeći od ovih tvrdnji, modeliranje neizvesnosti u ovom radu je izvršeno na primereniji način (Feili et al, 2011; Nestić et al, 2015). Bliže je ljudskom načinu razmišljanja da se relativne važnosti performansi postavljaju pomoću fazi matrice parova upoređenja, nego da se koristi direktan način procene (Nestić et al, 2015). U ovom radu, postavljena je fazi matrica parova upoređenja relativnih važnosti performansi (Feili et al, 2011). Takođe, u predloženoj metodi izvršena je provera konzistetnosti procena donosioca odluka tako što je u prvom koraku izvršena defazifikacija intervalnih tipa-2 fazi brojeva (Kahraman et al, 2014), a zatim, u drugom koraku je primenjena metoda sopstvenog vektora, kao što je definisano $u$ konvencionalnoj AHP metodi (Saaty, 1990), za proveru konzistentnosti procena donosioca odluka. Razvijeni postupak predstavlja jednu od razlika između predložene metode za određivanje težina performansi i nekih drugih metoda (Feili et al, 2011). Menadžment mere koje treba da se preduzmu u cilju poboljšanja performansi preduzeća i LS su zasnovane na rangu preduzeća. U ovom radu, kao i u svim analiziranim radovima iz literature, smatra se da menadžment mere definišu donosioci odluke na osnovu svog znanja i iskustva. Primenom genetrskog algoritma je određena optimalna vrednost poboljšanja izabranih performansi, što omogućava donosiocima odluke da bolje izaberu menadžment mere (Nestić et al, 2015). Osnovni nedostatak predložene metode je nepostojanje procedure za određivanje optimalne vrednosti poboljšanja performansi.

\section{PERFORMANSE LANCA SNABDEVANJA}

U ovom radu, razmatra se problem rangiranja preduzeća koja su integrisana u LS sa respektovanjem njegovih performansi. Pretpostavljeno je da se LS sastoji od jedne središnje organizacije, i većeg broja preduzeća koja se mogu posmatrati kao dobavljači središnje organizacije. Ovakava struktura karakteristična je za LS auto industrije. U preduzećima se proizvode svi proizvodi koji se koriste u procesu montaže, koja se ostvaruje $u$ središnjoj organizaciji. Efektivnost poslovanja svakog preduzeća utiče na efektivnost procesa montaže, i na ostvarenje operativinih i strategijskih ciljeva LS auto industrije. Formalno, razmatrana preduzeća mogu da se predstave skupom indeksa $E=\{1, \ldots, e, \ldots, E\}$. Ukupan broj razmatranih preduzeća je $E$, i indeks preduzeća je označen kao $e, e=1, \ldots, E$.

Stepen ostvarenja poslovnih ciljeva LS može da se odredi na osnovu vrednosti performansi preduzeća koja su integrisana u LS. Performanse LS su definisane u odgovarajućim standardima ili modelima (Bolstorff \& Rosenbaum, 2003). U ovom radu, performance LS su definisane prema SCOR (Bolstorff \& Rosenbaum, 2003). Nadalje, ukratko su opisane performanse LS, koje predstavljaju i performanse preduzeća koja su intergisana u razmatrani LS.

\section{Kompleksnost}

Koncept kompleksnosti je izučavan u okviru teorije grafova (Bezuidenhout, Bodhanya, Sanjika, Sibomana \& Boote, 2012), teorije menadžmenta LS (Pathak, Day, Nair, Sawaya \& Kristal, 2007) i dr. Otuda ne postoji jedinstvena definicija termina kompleksnost LS. C. Y. Cheng, T. L. Chen i Y. Y. Chen (2014) sugerišu da na kompleksnost LS utiče veliki broj faktora kao što su: veličina, stepen, i jačina veza između entiteta. Poznato je da veoma male promene kompleksnosti dovode do smanjenja stepena ostvarenja postavljenih ciljeva. Vrednost kompleksnosti na nivou svakog entiteta LS može da se odredi na osnovu procenjenih vrednosti KPI kompleksnosti LS.

U ovom radu, KPI su: (1) kompleksnost okruženja, (2) kompleksnost proizvodnog procesa, (3) operativna kompleksnost, i (4) kompleksnost koja nastaje usled integracije entiteta (Xu, Li, Govindan \& Xu, 2015). Vrednost kompleksnosti okruženja može da se proceni respektujući podatke o promenljivosti tražnje. 
Uzimajući u obzir informacije o složenosti prijema i skladištenja repromaterijala i poluproizvoda, složenosti tehnoloških postupaka, i o načinima kontrole kvaliteta procesa, poluproizvoda i proizvoda, može da se proceni vrednost kompleksnosti proizvodnog procesa. Vrednost operativne komplesnosti može da se odredi respektujući podatke o kompleksnosti: procesa planiranja i kontrole proizvodnje, unutrašnjeg transporta, metoda kontrole kvaliteta, potrebnih znanja i veština i dr. Na kompleksnost koja nastaje usled integracije entiteta LS utiču: broj entiteta, broj hijerarhijskih nivoa svakog entiteta, i veze koje postoje između entiteta unutar LS.

\section{Neizvesna tražnja}

U novije vreme, u gotovo svim LS može da se uoči da raste odstupanje između planirane količine i realne potražnje. Ova odstupanja nastaju usled mnogih promena koje su nastale: (a) u LS, i koje su - prema T. Maiti i B-C. Giri (2017) - nedostatak relevantnih informacija o promeni troškova proizvodnje i tražnje tokom vremena, i (b) u okruženju, na primer, razvoj i brza primena novih tehnologija, promene zahteva kupaca, i dr. Neizvesna tražnja dovodi do mnogih teškoća u planiranju proizvodnje preduzeća povezanih u LS (Felfel, Ayadi \& Masmoudi, 2016).

U literaturi su razmatrani brojni KPI, na osnovu kojih može da se odredi vrednost neizvesne tražnje. U ovom radu KPI neizvesne tražnje su: (1) neizvesnost kupaca, (2) tehnološke neizvesnosti, (3) ekonomska situacija, (4) tržišna konkurentnost i (5) pravna regulativa (Wong \& Boon-itt, 2008). Donosioci odluke svoje procene o vrednosti prvog KPI zasnivaju na informacijama o vrstama i količinama proizvoda koje su zahtevane od kupaca, promenama u vremenima isporuka, i fleksibilnosti isporuka. MU gotovom svakom LS postoji nedostatak pouzdanih informacija na osnovu kojih donosioci odluka mogu proceniti vrednost neizvesnosti kupaca. Neizvesnost tražnje značajno može da se smanji ako je LS orijentisan prema kupcu, a ne prema proizvodu (Frohlich \& Westbrook, 2002). Na tehnološku neizvesnost najviše utiče tehnološki nivo preduzeća. Što je tehnološki nivo viši, tehnološka neizvesnost je manja, i obrnuto. Procena ekonomske situacije (Bolstorff \& Rosenbaum, 2003) je povezana sa rastom tržišta, bruto domaćim proizvodom, stopom nezaposlenosti, stopom smrtnosti, i dr. Vrednost tržišne konkurentnosti može da se proceni uzimajući u razmatranje cenu proizvoda koju imaju konkurentski LS, vreme isporuke finalnih proizvoda, kao i stepen inovativnosti konkurentskih LS (Pal \& Kumar, 2008). Poslovanje preduzeća u LS mora da bude u skladu sa važećim pravnim propisima.

\section{Kvalitet}

Predviđanje tražnje i određivanje kvaliteta proizvoda je zasnovano na zahtevima koji potiču iz okruženja koje se brzo i neprekidno menja. Da bi se odgovorilo svim zahtevima, neophodno je da sistem menadžmenta kvalitetom bude integrisan u svako preduzeće koje predstavlja deo LS. Na ovaj način moguće je postići poboljšanje procesa proizvodnje u svakom preduzeću, a samim tim i u LS.

Postoje različite klasifikacije KPI razmatrane performanse (Bolstorff \& Rosenbaum, 2003; Sadikoglu \& Zehir, 2010). U ovom radu, usvojeni su na sledeći način definisiani KPI: (1) sposobnost, (2) kritični faktori uspeha, (3) strategijske komponente i (4) operativne komponente (Bolstorff \& Rosenbaum, 2003). Mnogi istraživači sugerišu da procena sposobnosti zavisi ne samo od kvaliteta proizvoda, već i od pouzdanosti isporuke, poverenja koje postoji između središnje organizacije i preduzeća, i dr. Vrednost kritičnih faktora uspeha se procenjuje prema rezultatima integracije koji su usmereni na eksterne stakeholder-e (Kuei \& Madu, 2001), i prema kvalitetu liderstva u LS (Kupers, 2000). Vrednosti KPI koji je označen kao strategijska komponenta su procenjene respektujući upravljanje organizacionom kulturom i upravljanje tehnologijama. Procena vrednosti operativne komponente je zasnovana na informacijama koliko se razlikuju tražnja središnje organizacije i obimi proizvodnje umreženih preduzeća, kakve su politike razvoja preduzeća, i dr. 


\section{Dodata vrednost}

Dodata vrednost se definiše kao razlika između cene proizvoda i troškova proizvodnje. U novije vreme, menadžment mnogih LS smatra da je ovo jedna od najvažnijih performansi LS (Presutti, 2003). Na osnovu rezultata iz literature može se zaključiti da se dodata vrednost većine proizvoda tokom vremena menja, i da ove promene nastaju, prvenstveno, usled promene troškova proizvodnje.

KPI ove performanse su definisani prema: (1) srednja vrednost prihoda stakeholder-a, (2) porast profita, (3) upotrebna vrednost imovine, (4) komunikacija unutar LS i sa kupcima, i (5) društvena odgovarnost LS-a.

\section{MODELIRANJE NEIZVESNOSTI}

U ovoj sekciji prikazan je način modeliranja neizvesnih i nepreciznih podataka u relativnoj važnosti performansi i njihovoj vrednosti na nivou razmatranih preduzeća. Intervalni fazi skup tipa-2 je predstavljen funkcijom raspodele mogućnosti. Gornja i donja funkcija intervalnog fazi skupa tipa-2 su funkcije raspodele mogućnosti fazi skupa (Dubois \& Prade, 1980; Zimmermann, 2001). Parametri ove funkcije su oblik, granulacija, i domen. Funkcije raspodele mogućnosti se određuju na osnovu subjektivnih procena donosilaca odluka, i treba da reflektuju znanje donosilaca odluka o razmatranim neizvesnostima. $U$ literaturi se najčešce koristi trapezoidni i trougaoni intervalni fazi broj tipa-2 za opisivanje mnogobrojnih i raznolikih neizvesnosti (Chen \& Lee, 2010; Kahraman et al, 2014; Zhang \& Zhang, 2017). Granulacija je definisana kao broj fazi skupova koji su pridruženi svakoj razmatranoj neizvesnosti. Pojedini autori (Lootsma, 1997) smatraju da donosilac odluke može da koristi najviše sedam lingvističkih iskaza za opisivanje neizvesnosti. U ovom radu, relativna važnost performansi može da se opiše sa pet, a njihove vrednosti na nivou svakog preduzeća pomoću sedam lingvističkih iskaza koji su modelirani intervalnim trougaonim fazi brojevima tipa-2. Domeni ovih fazi brojeva su definisani na zatvorenom intervalu u skupu realnih brojeva.

\section{Izbor odgovarajućih lingvističkih iskaza za procenu relativne važnosti performansi i vrednosti njihovih KPI}

Respektujući tip i veličinu problema, uvedena je pretpostavka da se relativna važnost svakog para performansi LS može adekvatno opisati pomoću pet lingvističkih iskaza koji su modelirani intervalnim trougaonim fazi brojevima tipa-2 na sledeći način:

veoma mala važnost $-\tilde{W}_{1}=((1,1,3.5 ; 1),(1,1,2,5 ; 0.75))$,

mala važnost $-\tilde{\tilde{W}}_{2}=((1,2,4 ; 1),(1.5,2,3.5 ; 0.75))$,

srednja važnost - $\tilde{\tilde{W}}_{3}=((1,3,5 ; 1),(2,3,4 ; 0.75))$,

velika važnost $-\stackrel{\tilde{W}}{W}_{4}=((2,4,5 ; 1),(1.5,4,4.5 ; 0.75)) \mathrm{i}$

najveća važnost - $\tilde{\tilde{W}}_{5}=((2.5,5,5 ; 1),(3,5,4,5 ; 0.75))$.

Domeni ovih intervalnih trougaonih fazi brojeva tipa$2 \mathrm{su}$ definisani na skupu realnih brojeva $\mathrm{u}$ interval [1-5]. Vrednost 1, odnosno vrednost 5 označava da performansa $p$ ima jednaku relativnu važnost, odnosno najveću važnost, $\mathrm{u}$ odnosu na performansu $p^{\prime}, p, p^{\prime}=$ $1, \ldots, P$, respektivno.

Preklapanja definisanih intervalnih trougaonih fazi brojeva tipa-2 kojima se modelira relativna važnost performansi LS su velika zato što ne postoji dovoljno znanja o njihovom prioritetu.

Vrednosti KPI svake razmatrane performanse su opisane pomoću sedam lingvističkih iskaza koji su modelirani intervalnim trougaonim fazi brojevima tipa-2:

veoma mala $(V M)$ - $((1,1,2.5 ; 1),(1,1,2 ; 0.6))$,

mala $(M)$ - $((1.5,3,4.5 ; 1),(2,3,4 ; 0.6))$,

gotovo srednja (GS) - $((2.5,4,5.5 ; 1),(3,3.5,5 ; 0.6))$,

srednja $(S)$ - $((3.5,5,6.5 ; 1),(4,5,6 ; 0.6))$,

gotovo visoka $(\mathrm{GV})$ - $((4.5,6,7.5 ; 1),(5,6,7 ; 0.6))$,

visoka $(\mathrm{V})$ - $((5.5,7,8.5 ; 1),(6,7,8 ; 0.6))$ i

veoma visoka (VV) - $((7.5,9,9 ; 1),(8,9,9 ; 0.6))$. 
Domeni intervalnih trougaonih fazi brojeva tipa-2, kojima su modelirane vrednosti performansi na nivou svakog preduzeća su definisani respektujući standardnu skalu mera (Saaty, 1990). Vrednost 1, odnosno, vrednost 9 označava da performansa $p, p=1, . ., P$ ima najmanju, odnosno, najveću vrednost, respektivno.

\section{Konstruisanje fazi matrice parova upoređenja performansi}

U literaturi može da se nađe veliki broj radova $u$ kojima su relativne važnosti atributa $\mathrm{u}$ smislu kojih se ocenjuju alternative zadate pomoću fazi matrice relativne važnosti atributa (Tadic, Aleksic, Mimovic, Puskaric \& Misita, 2016). Smatra se da je ovaj način bliži ljudskom načinu razmišljanja nego direktna procena. U ovom radu postavljena je fazi matrica parova upoređenja relativne važnosti performansi prema kojima se ocenjuju preduzeća LS-a. Relativna važnost svakog para kriterijuma je procenjena od strane strategijskog menadžmenta koji odluku donose konsenzusom. Elementi ove matrice su definisani kao relativna važnost performanse $p, p=1, \ldots, P$ prema performansi $p^{\prime}, p^{\prime}=1, \ldots, P, p \neq p^{\prime}$. Vrednosti ovih elemenata su opisane prethodno definisanim lingvističkim iskazima koji su modelirani intervalnim trougaonim fazi brojevima tipa-2 (Chen \& Lee, 2010):

$$
\tilde{\tilde{W}}_{p p^{\prime}}=\left(\left(\tilde{X}_{p p^{\prime}}^{U} ; \mu_{1}\left(X_{p p^{\prime}}^{U}\right),\left(\tilde{X}_{p p^{\prime}}^{L} ; \mu_{2}\left(X_{p p^{\prime}}^{L}\right)\right)\right)\right) .
$$

Trougaoni fazi brojevi tipa-1 su označeni kao:

$$
\tilde{X}^{U}=\left(a_{p p^{\prime}}^{U}, b_{p p^{\prime}}^{U}, c_{p p^{\prime}}^{U}\right) \text { i } \tilde{X}^{L}=\left(a_{p p^{\prime}}^{L}, b_{p p^{\prime}}^{L}, c_{p p^{\prime}}^{L}\right) \text {. }
$$

Referentne tačke intervalnog tipa-2 trougaonog fazi broja su označene kao: $a_{p p^{\prime}}^{U}, b_{p p^{\prime}}^{U}, c_{p p^{\prime}}^{U} a_{p p^{\prime}}^{L}, b_{p p^{\prime}}^{L}, c_{p p^{\prime}}^{L}$

Funkcija raspodele mogućnosti višeg, odnosno nižeg intervalnog trougaonog fazi broja tipa-2 je označena kao $\mu_{1}\left(\tilde{X}_{p p^{\prime}}^{U}\right)$, odnosno, $\mu_{2}\left(\tilde{X}_{p p^{\prime}}^{L}\right)$, respektivno.

Ako je relativna važnost performance $p^{\prime}$ veća od relativne važnosti performance $p$, tada vrednost elementa fazi matrice parova upoređenja relativne važnosti performansi može da se opiše kao: $\tilde{\tilde{W}}_{p p}=\left(\tilde{W}_{p p}\right)^{-1}=\left(\left(\frac{1}{c_{p p}^{U}}, \frac{1}{b_{p p}^{U}}, \frac{1}{a_{p p}^{U}} ; \min \left(\mu_{1}\left(\tilde{X}^{U}\right)\right), 1\right),\left(\frac{1}{c_{p p}^{L}}, \frac{1}{b_{p p}^{L}}, \frac{1}{a_{p p}^{L}} ; \min \left(\mu_{1}\left(\tilde{X}^{L}\right)\right), 1\right)\right)$. Na osnovu iskustva i rezultata dobre prakse, može da se tvrdi da donosioci odluke prave greške u proceni. Stoga, neophodno je prvo utvrditi konzistetnost procena strategijskih menadžera. U prvom koraku fazi matrica parova upoređenja relativne važnosti performansi se preslikavaju u matricu parova upoređenja relativnih važnosti performansi čije vrednosti su precizni brojevi. Reprezentativni skalari intervalnih trougaonih fazi brojeva tipa-2 su dobijeni primenom postupka defazifikacije (DTriT) (Kahraman et al, 2014):

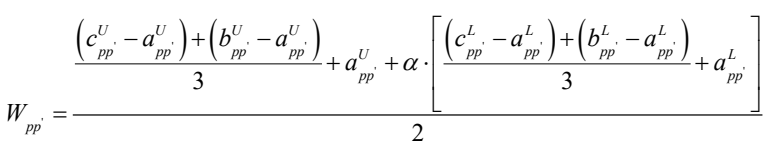

gde $\alpha$ označava maksimalnu vrednost funkcije raspodele mogućnosti za niži intervalni trougaoni fazi broj tipa-2.

U drugom koraku se određuje konzistetnost matrice parova upoređenja relativnih važnosti performansi primenom metode sopstvenog vektora (Saaty, 1990). Smatra se da su procene donosilaca odluka konzistentne ako je koeficijent konzistetnosti (C.I.) manji od 0.1. 


\section{Predloženi Algoritam}

Korak 1. Konstruišimo fazi matricu relativne važnosti

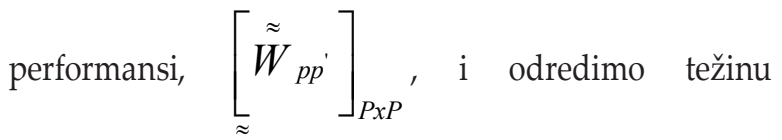
performance $p, w_{p}, p=1, \ldots, P$ :

$$
\tilde{w}_{p}=\frac{\tilde{r}_{p}}{\sum_{p=1}^{P} \approx \tilde{r}_{p}}
$$

gde je:

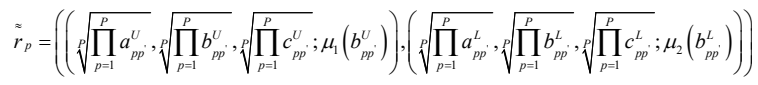

Težina performance je opisana intervalnim trougaonim fazi brojem tipa-2.

Korak 2. Procenimo vrednosti KPI svake performanse na nivou svakog preduzeća,

$$
\tilde{\tilde{V}}_{j e p}, j=1, . ., J_{p} ; e=1, \ldots, E ; p=1, \ldots, P
$$

Korak 3. Odredimo agregiranu vrednost performanse $p$ :

$$
\tilde{z}_{e p}=\frac{\tilde{V_{j e p}}}{J_{p}} e=1, \ldots, E ; p=1, \ldots, P
$$

Korak 4. Konstruišimo matricu odlučivanja, $\left[\tilde{\tilde{d}}_{e p}\right]_{E x P}$, tako da:

$$
\tilde{\tilde{d}}_{e p}=\tilde{w}_{p} \cdot \tilde{z}_{e p}
$$

Vrednosti matrice odlučivanja su opisane intervalnim trougaonim fazi brojevima tipa-2, na osnovu pravila množenja (Mendel \& Liu, 2017).

Reprezentativni skalar intervalnog trougaonog fazi broja tipa-2, $\tilde{d}_{e p}$ dobija se primenom postupka defazifikacije (Kahraman et al, 2014), $d_{e p}, e=1, . ., E, p=1, . ., P$.
Matrica odlučivanja može da se zapiše:

$$
\left[d_{e p}\right]_{E x P}
$$

Korak 5. Odredimo pozitivno idealno rešenje (PIS), $d_{p}^{+}, p=1, \ldots, P$ i negativno idealno rešenje (NIS), $d_{p}^{-}, p=1, \ldots, P$ respektujući tip performansi:

a) za benefitan tip:

$$
d_{p}^{+}=\max _{e=1, . ., E} d_{e p}, \quad d_{p}^{-}=\min _{e=1, . ., E} d_{e p}
$$

b) za troškovan tip:

$$
d_{p}^{+}=\min _{e=1, . ., E} d_{e p}, \quad d_{p}^{-}=\max _{e=1, . ., E} d_{e p}
$$

Korak 6. Izračunajmo Euklidove distance od PIS, i NIS, $y_{p}^{-}$za svaku vrednost elementa matrice odlučivanja:

$$
y_{p}^{+}=\sum_{p=1}^{P}\left(d_{p}^{+}-d_{e p}\right)^{2} \text { i } y_{p}^{-}=\sum_{p=1}^{P}\left(d_{p}^{-}-d_{e p}\right)^{2}
$$

Korak 7. Izračunajmo koeficijent približenja koji se pridružuje svakom preduzeću, prema proceduri koja je razvijena u konvencionalnoj TOPSIS metodi (Yoon \& Hwang, 1981), $k_{e}$ :

$$
k_{e}=\frac{y_{p}^{-}}{y_{p}^{-}+y_{p}^{+}}
$$

Korak 8. Sortirajmo vrednosti koeficijenta približenja u nerastući niz. Rang preduzeća je određen prema vrednostim $k_{e}$. Na prvom mestu u rangu se nalazi ono preduzeće kojem je pridružena najveća vrednost $k_{e}$. 


\section{Ilustrativni primer}

Razmatrani LS auto industrije u Centralnoj Srbiji uključuje središnje preduzeće (u ovom preduzeću se realizuje proces montaže finalnog proizvoda) i devet velikih preduzeća (u kojma se proizvode komponente, koje se ugrađuju u finalni proizvod). Prihod koji se ostvaruje u LS automobilske industrije ima veliki uticaj na bruto domaći proizvod svake zemlje, a posebno $\mathrm{u}$ zemljama u razvoju. Performanse LS su definisane na osnovu preporuka P. Bolstorff-a i R. Rosenbaum-a (2003). Za procenu relativne važnosti performansi, i njihovih vrednosti definisani su odgovarajući upitnici, koji su poslati strategijskom menadžmentu LS-a i menadžment timovima (menadžer proizvodnje, menadžer kvaliteta, finansijski menadžer, i menadžer snabdevanja) koji su uključeni u LS, respektivno. Donosioci odluka su na postavljena pitanja svakom paru performansi, odnosno, svakoj performansi pridružili jedan od unapred definisanih lingvističkih iskaza. Donosioci odluka su odluke donosili konsenzsom.

Postavimo fazi matricu relativne važnosti performansi na nivou LS (Korak 1 razvijenog Algoritma):

$$
\left[\begin{array}{cccc}
((1,1,1 ; 1),(1,1,1 ; 1)) & 1 / \tilde{W}_{1} & 1 / \tilde{W}_{3} & 1 / \tilde{W}_{4} \\
\tilde{W}_{1} & ((1,1,1 ; 1),(1,1,1 ; 1)) & 1 / \tilde{W}_{2} & 1 / \tilde{W}_{3} \\
\tilde{W}_{3} & \tilde{W}_{2} & ((1,1,1 ; 1),(1,1,1 ; 1)) & 1 / \tilde{W}_{2} \\
\tilde{W}_{4} & \tilde{W}_{3} & \tilde{W}_{2} & ((1,1,1 ; 1),(1,1,1 ; 1))
\end{array}\right]_{4 \times 4}
$$

Preslikajmo fazi matricu parova upoređenja relativne važnosti performansi u matricu parova upoređenja relativnih važnosti performansi primenom postupka defazifikacije, DTriT (Kahraman et al, 2014), i odredimo konzistentnost procene strategijskih menadžera:

$$
\left[\begin{array}{cccc}
1 & 0.681 & 0.422 & 0.301 \\
1.468 & 1 & 0.473 & 0.422 \\
2.369 & 2.114 & 1 & 0.473 \\
3.322 & 2.369 & 2.114 & 1
\end{array}\right], \text { C.I. }=0.258
$$

Koristeći izraze (1) i (2) izračunavaju se ponderi razmatranih performansi. Postupak koji je prikazan (Korak 1 razvijenog Algoritma) je ilustrovan na primeru izračunavanja pondera peformanse koja je označena kao kompleksnost $(p=1)$. $\tilde{r}_{1}=((0.327,0.536,0.841 ; 1),(0.386,0.536,0.759 ; 0.75))$

$\sum_{p=1}^{4} \tilde{\tilde{r}}_{p}=((0.327,0.536,0.841 ; 1),(0.386,0.536,0.759 ; 0.75))+$ $+\left((0.473,0.639,1.268 ; 1),\left(0.518,0.639,0.955^{\prime} 0.75\right)\right)+$ $+((0.707,1.316,2.115 ; 1),(0.963,1.316,1.749 ; 0.75))+$ $+((1.189,2.213,3.162 ; 1),(1.456,2.213,2.817 ; 0.75))=$ $=((2.696,4.704,7.386 ; 1),(3.323,4.705,6.2780 ; 0.75))$ $\tilde{w}_{1}=\frac{((0.327,0.536,0.841 ; 1),(0.386,0.536,0.759 ; 0.75))}{\left((2.696,4.704,7.486 ; 1),\left(3.323,4.705,6.280^{\prime} 0.75\right)\right)}=$ $=((0.327 / 7.486,0.536 / 4.704,0.841 / 2.696 ; 1))$, $((0.386 / 6.280 .0 .536 / 4.705,0.759 / 3.323 ; 0.75))$ $\tilde{w}_{1}=((0.044,0.114,0.312 ; 1),(0.061,0.114,0.228 ; 0.75))$

Na isti način se dobijaju ponderi ostalih razmatranih performansi, i one su:

$\tilde{w}_{2}=((0.063,0.136,0.470 ; 1),(0.082,0.136,0.287 ; 0.75))$

$\tilde{w}_{3}=((0.094,0.279,0.784 ; 1),(0.153,0.279,0.526 ; 0.75))$

$\tilde{w}_{4}=((0.161,0.471,1.173 ; 1),(0.232,0.471,0.848 ; 0.75))$

Procenjene vrednosti KPI (Korak 2 razvijenog Algoritma) su date u Tabeli 1.

Agregirane vrednosti performansi se izračunavaju prema izrazu 3 (Tabela 2).

Ponderisane vrednosti performansi na nivou svakog preduzeća se izračunavaju prema izrazu (5). Postupak množenja dva intervalna trougaona fazi broja tipa-2 je ilustrovan sledećim primerom:

$$
\begin{aligned}
& \tilde{\tilde{d}}_{63}=((5.7,7.2,8.4 ; 1),(6.2,7.2 .8 ; 0.6)) \\
& \cdot((0.094,0.279,0.784 ; 1),(0.153,0.279,0.526 ; 0.75))= \\
& =((0.54,2.01,6.59 ; 1),(0.95,2.01,4.21 ; 0.6))
\end{aligned}
$$


Tabela 1 Procenjene vrednosti KPI na nivou svakog preduzeća

\begin{tabular}{|c|c|c|c|c|c|c|c|c|c|}
\hline & \multicolumn{9}{|c|}{ Preduzeća } \\
\hline & $e=1$ & $e=2$ & $e=3$ & $e=4$ & $e=5$ & $e=6$ & $e=7$ & $e=8$ & $e=9$ \\
\hline \multirow{4}{*}{ 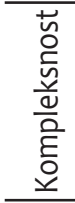 } & GS & $M$ & $G S$ & $M$ & $M$ & $G S$ & $M$ & $G S$ & $G S$ \\
\hline & GV & $S$ & GV & $S$ & $S$ & GV & $S$ & GV & GV \\
\hline & $S$ & $S$ & GV & $S$ & $S$ & GV & $S$ & GV & GV \\
\hline & GV & $S$ & V & GV & GV & V & $G V$ & V & V \\
\hline \multirow{5}{*}{ 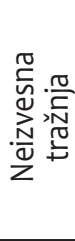 } & $M$ & $M$ & $M$ & $M$ & VM & VM & VM & VM & VM \\
\hline & $M$ & M & $M$ & $M$ & VM & VM & VM & VM & VM \\
\hline & GS & GS & $M$ & $M$ & $M$ & $M$ & $M$ & VM & VM \\
\hline & M & $M$ & $M$ & $M$ & $M$ & VM & VM & $M$ & $M$ \\
\hline & VM & $M$ & $M$ & VM & VM & VM & $M$ & VM & $M$ \\
\hline \multirow{4}{*}{ 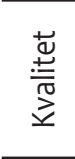 } & $\mathrm{V}$ & V & VV & V & V & V & V & VV & WV \\
\hline & VV & VV & VV & WV & V & V & VV & V & WV \\
\hline & VV & W & VV & V & VV & V & V & V & V \\
\hline & V & VV & VV & WV & V & VV & V & VV & V \\
\hline \multirow{5}{*}{ 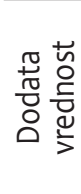 } & V & VV & V & WV & $\mathrm{VV}$ & $\bar{V}$ & $\mathrm{VV}$ & $\bar{V}$ & $\mathrm{~V}$ \\
\hline & VV & VV & V & V & VV & VV & VV & VV & WV \\
\hline & V & W & V & V & V & V & V & WV & W \\
\hline & V & V & V & V & V & V & VV & VV & V \\
\hline & V & V & GV & V & V & $G V$ & V & V & V \\
\hline
\end{tabular}

Fazi matrica odlučivanja (Korak 4 razvijenog Algoritma) prikazana u Tabeli 3.

Vrednosti PIS i NIS su izračunate prema matrici odlučivanja (Korak 5 razvijenog Algoritma) - Tabela 4.

Vrednosti koeficijenta približenja i rang razmatranih preduzeća su dobijeni prema razvijenom Algoritmu (Korak 6 do Korak 8) - Tabela 5.

\section{DISKUSIJA REZULTATA}

Respektujući rezulatate koji su prikazani u Tabeli 5 može da se zaključi da su preduzeća $(\mathrm{e}=8)$ i $(\mathrm{e}=2)$ najefikasnija u razmatranom LS, jer se nalaze na prvom, odnosno, drugom mestu $u$ rangu, respektivno. Na poslednjem mestu u rangu se nalazi preduzeće $(e=1)$. Kako je vrednost koeficijenta bliskosti preduzeća (e = 1) gotovo jednaka vrednostima koeficijenta bliskosti preduzeća $(\mathrm{e}=4)$ i preduzeća $(\mathrm{e}=6)$ može da se kaže da menadžment treba da preduzme istovremeno odgovarajuće mere za poboljšanja performansi preduzeća ( $\mathrm{e}=1$, e $=4$ i e $=6$ ) koja se nalaze na

Izvor: Autori

Tabela 2 Agregirane vrednosti performansi

\begin{tabular}{|c|c|c|c|c|}
\hline & $\mathrm{p}=1$ & $p=2$ & $p=3$ & $p=4$ \\
\hline$e=1$ & $\begin{array}{l}((3.25,4 \cdot 75,6.25 ; 1), \\
(3 \cdot 75,4 \cdot 62,5 \cdot 75 ; 0.6))\end{array}$ & $\begin{array}{l}((1.6,2.8,4 \cdot 3 ; 1) \\
(2,4,2.8,3 \cdot 8 ; 0.6))\end{array}$ & $\begin{array}{l}((6.5,8,8.75 ; 1) \\
(7,8,8.5 ; 0.6))\end{array}$ & $\begin{array}{l}((5 \cdot 9,7 \cdot 4,8.6 ; 1) \\
(6.4,7 \cdot 4.8 ; 0.6))\end{array}$ \\
\hline$e=2$ & $\begin{array}{l}((3,4 \cdot 5,6 ; 1) \\
(3 \cdot 5,4 \cdot 5,5 \cdot 5 ; 0.6))\end{array}$ & $\begin{array}{l}((1.7,3 \cdot 2,4 \cdot 7 ; 1) \\
(2 \cdot 2,4 \cdot 3 \cdot 2,4 \cdot 2 ; 0.6))\end{array}$ & $\begin{array}{l}((7,8.5,8.87 ; 1) \\
(7 \cdot 5,8.5,8.75 ; 0.6))\end{array}$ & $\begin{array}{l}((6.7,8.2,8.8 ; 1) \\
(7.2,8.2,8.6 ; 0.6))\end{array}$ \\
\hline$e=3$ & $\begin{array}{l}((4.25,5 \cdot 75,7 \cdot 25 ; 1) \\
(4 \cdot 75,5 \cdot 75,6.75 ; 0.6))\end{array}$ & $\begin{array}{l}((1.5,3,4 \cdot 5 ; 1) \\
(2,3.8,4 ; 0.6))\end{array}$ & $\begin{array}{l}((7 \cdot 5,9,9 ; 1) \\
(8,9,9 ; 0.6))\end{array}$ & $\begin{array}{l}((5 \cdot 3,6.8,8.3 ; 1), \\
(5.8,6.8 .7 .8 ; 0.6))\end{array}$ \\
\hline$e=4$ & $\begin{array}{l}((4 \cdot 25,5 \cdot 75,7 \cdot 25 ; 1), \\
(4 \cdot 75,5 \cdot 75,6.75 ; 0.6))\end{array}$ & $\begin{array}{l}((1.4,2.6,4 \cdot 4 ; 1) \\
(1.8,2.6,3.6 ; 0.6))\end{array}$ & $\begin{array}{l}((6.5,8,8.75 ; 1) \\
(7,8,8.5 ; 0.6))\end{array}$ & $\begin{array}{l}((5 \cdot 9,7 \cdot 4,8.6 ; 1), \\
(6.4,7 \cdot 4 \cdot 8 ; 0.6))\end{array}$ \\
\hline$e=5$ & $\begin{array}{l}((3.25,4 \cdot 75,7 \cdot 25 ; 1), \\
(3 \cdot 75,4.75,5 \cdot 75 ; 0.6))\end{array}$ & $\begin{array}{l}((1.2,1.8,3.3 ; 1) \\
(1.4,1.8,2.8 ; 0.6))\end{array}$ & $\begin{array}{l}((6,7 \cdot 5,8.62 ; 1) \\
(6.5,7 \cdot 5,8.25 ; 0.6))\end{array}$ & $\begin{array}{l}((6.3,7.8,8.7 ; 1) \\
(6.8,7.8 .8 \cdot 4 ; 0.6))\end{array}$ \\
\hline$e=6$ & $\begin{array}{l}((4.25,5 \cdot 75,7 \cdot 25 ; 1), \\
(4 \cdot 75,5 \cdot 75,6.75 ; 0.6))\end{array}$ & $\begin{array}{l}((1.1,1.4,2 \cdot 9 ; 1) \\
(1.2,1.4,2.4 ; 0.6))\end{array}$ & $\begin{array}{l}((6,7.5,8.62 ; 1) \\
(6.5,7 \cdot 5,8.25 ; 0.6))\end{array}$ & $\begin{array}{l}((5 \cdot 7,7 \cdot 2,8.4 ; 1), \\
(6.2,7.2 .8 ; 0.6))\end{array}$ \\
\hline$e=7$ & $\begin{array}{l}((3.25,4 \cdot 75,7.25 ; 1) \\
(3.75,4 \cdot 75,5 \cdot 75 ; 0.6))\end{array}$ & $\begin{array}{l}((1.2,1.8,3 \cdot 3 ; 1) \\
(1.4,1.8,2.8 ; 0.6))\end{array}$ & $\begin{array}{l}((6,7 \cdot 5,8.62 ; 1) \\
(6.5,7 \cdot 5,8.25 ; 0.6))\end{array}$ & $\begin{array}{l}((7 \cdot 1,8 \cdot 6,8 \cdot 9 ; 1) \\
(7 \cdot 6,8.6 .8 .8 ; 0.6))\end{array}$ \\
\hline$e=8$ & $\begin{array}{l}((4.25,5 \cdot 75,7.25 ; 1) \\
(4 \cdot 75,5 \cdot 75,6.75 ; 0.6))\end{array}$ & $\begin{array}{l}((1.1,1.4,2 \cdot 9 ; 1) \\
(1.2,1.4, .2 .4 ; 0.6))\end{array}$ & $\begin{array}{l}((6.5,8,8.75 ; 1) \\
(7,8,8.5 ; 0.6))\end{array}$ & $\begin{array}{l}((6.7,8.2,8.8 ; 1), \\
(7.2,8.2,8.6 ; 0.6))\end{array}$ \\
\hline$e=9$ & $\begin{array}{l}((4.25,5 \cdot 75,7.25 ; 1), \\
(4 \cdot 75,5 \cdot 75,6.75 ; 0.6))\end{array}$ & $\begin{array}{l}((1.2,1.8,3 \cdot 3 ; 1), \\
(1.4,1.8,2.8 ; 0.6))\end{array}$ & $\begin{array}{l}((6.5,8,8.75 ; 1), \\
(7,8,8.5 ; 0.6)) \\
\end{array}$ & $\begin{array}{l}((6.3,7.8,8.7 ; 1) \\
(6.8,7.8 .8 .4 ; 0.6))\end{array}$ \\
\hline
\end{tabular}

Izvor: Autori 
Tabela 3 Fazi matrica odlučivanja

\begin{tabular}{|c|c|c|c|c|}
\hline & $p=1$ & $p=2$ & $p=3$ & $p=4$ \\
\hline$e=1$ & $\begin{array}{l}((0.14,0.54,1.95 ; l) \\
(0.22,0.53,1.31 ; 0.6))\end{array}$ & $\begin{array}{l}((0.1,0.38,2.02 ; 1) \\
(0.19,0.38,1.09 ; 0.6))\end{array}$ & $\begin{array}{l}((0.61,2.23,6.86 ; 1) \\
(1.07,2.23,4.47 ; 0.6))\end{array}$ & $\begin{array}{l}((0.95,3.49,10.09 ; 1) \\
(1.48,3.49,6.78 ; 0.6))\end{array}$ \\
\hline$e=2$ & $\begin{array}{l}((0.13,0.51,1.87 ; 1) \\
(0.21,0.51,1.25 ; 0.6))\end{array}$ & $\begin{array}{l}((0.11,0.44,2.21 ; 1) \\
(0.18,0.44,1.21 ; 0.6))\end{array}$ & $\begin{array}{l}((0.66,2.37,6.95 ; 1) \\
(1.15,2 \cdot 37,4.61 ; 0.6))\end{array}$ & $\begin{array}{l}((1.08,3 \cdot 86,15 \cdot 23 ; 1) \\
(1.67,3 \cdot 38,7.29 ; 0.6))\end{array}$ \\
\hline$e=3$ & $\begin{array}{l}((0.19,0.66,2.26 ; 1) \\
(0.29,0.66,1.54 ; 0.6))\end{array}$ & $\begin{array}{l}((0.09,0.41,2.11 ; 1) \\
(0.16,0.41,1.15 ; 0.6))\end{array}$ & $\begin{array}{l}((0.71,2.51,7.06 ; 1) \\
(1.22,2.51,4 \cdot 73 ; 0.6))\end{array}$ & $\begin{array}{l}((0.85,3.21,9.74 ; 1) \\
(1.35,3.21,6.78 ; 0.6))\end{array}$ \\
\hline$e=4$ & $\begin{array}{l}((0.19,0.66,2.26 ; 1) \\
(0.29,0.66,1.54 ; 0.6))\end{array}$ & $\begin{array}{l}((0.09,0.35,2.07 ; 1) \\
(0.15,0.35,1.03 ; 0.6))\end{array}$ & $\begin{array}{l}((0.61,2.23,6.86 ; 1) \\
(1.07,2.23,4.47 ; 0.6))\end{array}$ & $\begin{array}{l}((0.95,3.49,10.09 ; 1), \\
(1.48,3.49,6.78 ; 0.6))\end{array}$ \\
\hline$e=5$ & $\begin{array}{l}((0.14,0.54,2.26 ; 1) \\
(0.23,0.54,1.31 ; 0.6))\end{array}$ & $\begin{array}{l}((0.08,0.24,1.55 ; 1) \\
(0.11,0.24,0.8 ; 0.6))\end{array}$ & $\begin{array}{l}((0.56,2.09,6.76 ; 1), \\
(0.99,2.09,4.34 ; 0.6))\end{array}$ & $\begin{array}{l}((1.01,3.67,10.21 ; 1) \\
(1.58,3.67,7.12 ; 0.6))\end{array}$ \\
\hline$e=6$ & $\begin{array}{l}((0.19,0.66,2.26 ; 1) \\
(0.29,0.66,1.54 ; 0.6))\end{array}$ & $\begin{array}{l}((0.07,0.19,1.36 ; 1) \\
(0.09,0.19, .0 .69 ; 0.6))\end{array}$ & $\begin{array}{l}((0.56,2.09,6.76 ; 1) \\
(0.99,2.09,4.34 ; 0.6))\end{array}$ & $\begin{array}{l}((0.92,3 \cdot 39,9.85 ; 1) \\
(1.44,3 \cdot 39,6.78 ; 0.6))\end{array}$ \\
\hline$e=7$ & $\begin{array}{l}((0.14,0.54,2.26 ; 1) \\
(0.23,0.54,1.31 ; 0.6))\end{array}$ & $\begin{array}{l}((0.08,0.24,1.55 ; 1) \\
(0.11,0.24,0.8 ; 0.6))\end{array}$ & $\begin{array}{l}((0.56,2.09,6.76 ; 1), \\
(0.99,2.09,4.34 ; 0.6))\end{array}$ & $\begin{array}{l}((1.14,4 \cdot 05,10.44 ; 1), \\
(1.76,4.05,7.46 ; 0.6))\end{array}$ \\
\hline$e=8$ & $\begin{array}{l}((0.19,0.66,2.26 ; 1), \\
(0.29,0.66,1.54 ; 0.6))\end{array}$ & $\begin{array}{l}((0.07,0.19,1.36 ; 1) \\
(0.09,0.19, .0 .69 ; 0.6))\end{array}$ & $\begin{array}{l}((0.61,2.23,6.86 ; 1) \\
(1.07,2.23,4.47 ; 0.6))\end{array}$ & $\begin{array}{l}((1.08,3 \cdot 86,15 \cdot 23 ; 1) \\
(1.67,3 \cdot 38,7.29 ; 0.6))\end{array}$ \\
\hline$e=9$ & $\begin{array}{l}((0.19,0.66,2.26 ; 1), \\
(0.29,0.66,1.54 ; 0.6))\end{array}$ & $\begin{array}{l}((0.08,0.24,1.55 ; 1) \\
(0.11,0.24,0.8 ; 0.6))\end{array}$ & $\begin{array}{l}((0.61,2.23,6.86 ; 1) \\
(1.07,2.23,4.47 ; 0.6))\end{array}$ & $\begin{array}{l}((1.01,3 \cdot 67,10.21 ; 1) \\
(1.58,3 \cdot 67,7 \cdot 12 ; 0.6))\end{array}$ \\
\hline
\end{tabular}

Izvor: Autori

Tabela 4 Matrica odlučivanja, PIS i NIS

\begin{tabular}{|c|c|c|c|c|}
\hline & $p=1$ & $p=2$ & $p=3$ & $p=4$ \\
\hline$e=1$ & 0.6443 & 0.5827 & 2.3937 & 3.5967 \\
\hline$e=2$ & 0.6153 & 0.6430 & 2.4763 & 4.5957 \\
\hline$e=3$ & 0.7673 & 0.6070 & 2.5593 & 3.4340 \\
\hline$e=4$ & 0.7673 & 0.5713 & 2.3937 & 3.5967 \\
\hline$e=5$ & 0.6443 & 0.4267 & 2.3103 & 3.7187 \\
\hline$e=6$ & 0.7673 & 0.3670 & 2.3103 & 3.5210 \\
\hline$e=7$ & 0.6443 & 0.4267 & 2.3103 & 3.9320 \\
\hline$e=8$ & 0.7673 & 0.3670 & 2.3937 & 4.5957 \\
\hline$e=9$ & 0.7673 & 0.4267 & 2.3937 & 3.7187 \\
\hline PIS & 0.6153 & 0.3670 & 2.5593 & 4.5957 \\
\hline NIS & 0.7673 & 0.6430 & 2.3103 & 3.4340 \\
\hline
\end{tabular}

Izvor: Autori
Tabela 5 Vrednosti koeficijenta približenja i rang preduzeća

\begin{tabular}{|c|c|c|c|c|}
\hline & $\mathrm{y}_{\mathrm{p}}^{+}$ & $y_{\bar{p}}$ & $\mathrm{k}_{\mathrm{e}}$ & Rang \\
\hline$e=1$ & 1.0356 & 0.2285 & 0.1103 & 9 \\
\hline$e=2$ & 0.2882 & 1.1833 & 0.8041 & 2 \\
\hline$e=3$ & 1.1959 & 0.2516 & 0.5000 & 3 \\
\hline$e=4$ & 1.0442 & 0.1964 & 0.1583 & 8 \\
\hline$e=5$ & 0.9141 & 0.3781 & 0.2714 & 6 \\
\hline$e=6$ & 1.1136 & 0.2894 & 0.2063 & 7 \\
\hline$e=7$ & 0.7119 & 0.5487 & 0.4353 & 4 \\
\hline$e=8$ & 0.2248 & 1.1970 & 0.8419 & 1 \\
\hline$e=9$ & 0.9073 & 0.3671 & 0.2880 & 5 \\
\hline
\end{tabular}

Izvor: Autori 
poslednjem, pretposlednjem i sedmom mestu u rangu. U sva tri preduzeća vrednosti performanse kvalitet $(\mathrm{p}=$ 3) i dodata vrednost $(p=4)$ imaju najmanje ponderisane vrednosti. S toga se može zaključiti da je neophodno da menadžment tim preduzme prvo mere koje treba da dovedu do poboljšanja ovih performansi. Poboljšanje performanse kvaliteta $(p=3)$ može da se postigne kroz poboljšanje strategije snabdevanja, uvođenjem novih koncepata liderstva, itd. Poboljšanje strategije snabdevanja može da se realizuje kroz ostvarivanje partnerskog odnosa sa dobavljačima repro materijala, uvođenjem informacionih sistema pomoću kojih se poboljšava komunikacija između svih entiteta $u$ LS-u, primenom sistema za upravljanje zalihama i proizvodnjom, itd. Povećanje dodatne vrednost $(\mathrm{p}=$ 4) preduzeća (e $=1$, e $=4$ i e $=6$ ) može da se postigne primenom lean principa, kao na primer pull sistema.

Ponderisana vrednost performanse kompleksnosti ( $p$ = 1) u preduzećima $(\mathrm{e}=4)$ i $(\mathrm{e}=6)$ ima veću vrednost od vrednosti iste performanse preduzeća koje se nalazi na prvom mestu $u$ rangu $(e=8)$. Stoga, menadžment tim treba da preduzme odgovarajuće mere u cilju smanjivanja vrednosti kompleksnosti u preduzećima $(\mathrm{e}=4)$ i $(\mathrm{e}=6)$. Smanjenje kompleksnosti može da se realizuje kroz unapređenje mape toka vrednosti. Određivanjem mape toka vrednosti moguće je uočiti sve nepotrebne potprocese i aktivnosti procesa proizvodnje. Njihovom eliminacijom smanjuje se kompleksnost preduzeća. Kompleksnost LS može da se smanji i kroz primenu metoda reinženjeringa procesa i proizvoda.

\section{ZAKLJUČAK}

Upravljanje i poboljšanje performansa LS predstavlja jedan od važnih menadžment zadataka. Rešenje ovog problema dovodi do povećanja konkurentnosti i održivost LS $u$ dužem vremenskom intervalu. Istovremenim poboljašvanjem performansi svih entiteta LS-a, efektivnost LS sigurno će se povećati. Takođe, ako se primeni ovaj scenario, dolazi do velike potršnje resursa (vremena, novca, itd.). Da bi se ostvarilo povećanje efektivnosti lanca snabdevanja, uz najmanji mogući utrošak resursa, neophodno je da se odrede preduzeća LS čije performanse treba poboljšavati. Pokazano je da se primenom analitičkih metoda u ocenjivanju i rangiranju preduzeća dobijaju tačniji rezultati, nego kada se koriste intuitivne metode za donošenje odluka.

Glavni doprinos ovog rada je razvoj modela za ocenu i rangiranje preduzeća koja su integrisana u LS respektujući performanse LS i njihove pondere. Kako LS postoji u okruženju koje se brzo menja, relativna važnost performansi i nijhove vrednosti su opisane intervalnim trougaonim fazi brojevima tipa-2. Može se smatrati da je ovaj pristup u modeliranju neizvesnih i nepreciznih podataka sasvim odgovarajući kada ne postoji dovoljno informacija o prirodi neizvesnosti. Pokazano je da rangiranje preduzeća može da bude postavljeno kao problem višeatributivnog odlučivanja. Na osnovu dobijenog ranga preduzeća, određuje se prioritet preduzeća u kojima je potrebno izvršiti poboljšanje performansi. Prioritet mera u razmatranim preduzećima se određuje upoređivanjem tekućih i ciljnih vrednosti performansi.

Predloženi model je testiran na realnim podacima koji su dobijeni iz LS automobilske industrije koji egzistira u Centralnoj Srbiji. Ovaj rad ima doprinose $\mathrm{u}$ istraživačkom i praktičnom domenu. Modeliranje neizvesnosti i modifikacija konvencionalne TOPSIS metode predstavljaju osnovne doprinose $u$ istraživačkom domenu. Razvijeni model je fleksibilan u smislu promene broja performansi, njihovih važnosti i vrednosti, pa stoga može da se primeni i za rešavanje sličnih problema koji egzistiraju u različitim industrijskim granama. U praktičnom domenu, doprinos ovog rada može da se označi kao smanjivanje resursa koje je potrebno utrošiti za poboljšanje efektivnosti preduzeća integrisanih u LS.

Glavno ograničenje modela je nepostojanje jedinstvene klasifilacije performansi LS.

Buduće istraživanje treba da obuhvati razvoj i primenu egzaktnih metoda za utvrđivanje optimalnih vrednosti poboljšanja performansi. Razvijeni model može da se primeni i u LS iz različitih privrednih grana. 


\section{REFERENCE}

Anitha, J. (2014). Determinants of employee engagement and their impact on employee performance. International journal of productivity and performance management, 63(3), 308-323. doi.org/10.1108/IJPPM-01-2013-0008

Baas, S. M., \& Kwakernaak, H. (1977). Rating and ranking of multiple-aspect alternatives using fuzzy sets. Automatica, 13(1), 47-58. doi.org/10.1016/0005-1098(77)90008-5

Beamon, B. M. (1999). Measuring supply chain performance. International journal of operations \& production management, 19(3), 275-292. doi.org/10.1108/01443579910249714

Behery, M., Jabeen, F., \& Parakandi, M. (2014). Adopting a contemporary management system: A fast-growth smallto-medium enterprise (FGSME) in the UAE. International Journal of Productivity and Performance Management, 63(1), 2243. doi.org/10.1108/IJPPM-07-2012-0076

Bezuidenhout, C. N., Bodhanya, S., Sanjika, T., Sibomana, M., \& Boote, G. L. N. (2012). Network-analysis approaches to deal with causal complexity in a supply network. International Journal of Production Research, 50(7), 1840-1849. doi.org/10.1080/00207543.2011.575088

Bolstorff, P., \& Rosenbaum, R. (2003). Supply chain excellence. New York, NY: American Management Association.

Castillo, O., \& Melin, P. (2012). Recent advances in interval Type2 fuzzy systems. (Vol. 1), New York, NY: Springer Science \& Business Media.

Chang, D. Y. (1996). Applications of the extent analysis method on fuzzy AHP. European journal of operational research, 95(3), 649-655. doi.org/10.1016/0377-2217(95)00300-2

Chen, S. M., \& Lee, L. W. (2010). Fuzzy multiple attributes group decision-making based on the interval type-2 TOPSIS method. Expert systems with applications, 37(4), 27902798. doi.org/10.1016/j.eswa.2009.09.012

Cheng, C. Y., Chen, T. L., \& Chen, Y. Y. (2014). An analysis of the structural complexity of supply chain networks. Applied Mathematical Modelling, 38(9-10), 2328-2344. doi.org/10.1016/j. apm.2013.10.016
Cocca, P., \& Alberti, M. (2010). A framework to assess performance measurement systems in SMEs. International Journal of Productivity and Performance Management, 59(2), 186-200. doi.org/10.1108/17410401011014258

Dubois, D., \& Prade, H. (1980). Fuzzy sets and systems. New York, NY: Academic Press.

Feili, H. R., Farahani, N. V., \& Vesaghi, N. (2011). Integration of fuzzy analytic hierarchy process (FAHP) with balance score card (BSC) in order to evaluate the performance of information technology in industry. The Journal of Mathematics and Computer Science, 2(2), 271-283.

Felfel, H., Ayadi, O., \& Masmoudi, F. (2016). Multi-objective stochastic multi-site supply chain planning under demand uncertainty considering downside risk. Computers $\mathcal{E}$ Industrial Engineering, 102, 268-279. doi.org/10.1016/j. cie.2016.10.025

Frohlich, M. T., \& Westbrook, R. (2002). Demand chain management in manufacturing and services: Web-based integration, drivers and performance. Journal of Operations Management, 20(6), 729-745. doi.org/10.1016/S02726963(02)00037-2

Hakimollahi, M., Naini, S. J., Bagherpour, M., Jafari, S., \& Shahmoradi, A. (2012). Balanced scorecard with fuzzy inference as a performance measurement in an automotive manufacturing line. International Journal of Automotive Engineering, 2(4), 276-283.

Kahraman, C., Öztayşi, B., Sarı, İ. U., \& Turanoğlu, E. (2014). Fuzzy analytic hierarchy process with interval type-2 fuzzy sets. Knowledge-Based Systems, 59, 48-57. doi.org/10.1016/j. knosys.2014.02.001

Kaplan, S. R., \& Norton, P. D. (2008). The execution premium: Linking strategy to operations for competitive advantages. Boston, USA: Harvard Business School Publishing Corporation.

Kuei, C. H., \& Madu, C. N. (2001). Identifying critical success factors for supply chain quality management (SCQM). Asia Pacific Management Review, 6(4), 409-423.

Kupers, R. (2000). What organizational leaders should know about the new science of complexity. Complexity, $6(1), \quad 14-19 . \quad$ doi:10.1002/1099-0526(200009/10)6:1<14::aidcplx1002>3.0.c0;2-6 
Lootsma, F. (1997). Fuzzy logic for planning and decision making. New York, NY: Springer. doi:10.1007/978-1-4757-2618-3

Maiti, T., \& Giri, B. C. (2017). Two-period pricing and decision strategies in a two-echelon supply chain under pricedependent demand. Applied Mathematical Modelling, 42, 655674. doi.org/10.1016/j.apm.2016.10.051

Mendel, J. M., \& Liu, F. (2007). Super-exponential convergence of the Karnik-Mendel algorithms for computing the centroid of an interval type-2 fuzzy set. IEEE Transactions on Fuzzy Systems, 15(2), 309-320. doi:10.1109/tfuzz.2006.882463

Merigó, J. M., \& Casanovas, M. (2008). Using fuzzy numbers in heavy aggregation operators. International Journal of Information Technology, 4(3), 177-182.

Neely, A. D., Gregory, M., \& Platts, K. (1995). Performance measurement system design: A literature review and research agenda. International Journal of Operations \& Production Management, 15(4), 80-116. doi. org/10.1108/01443579510083622

Nestic, S., Djordjevic, A., Puskaric, H., Zahar Djordjevic, M., Tadic, D., \& Stefanovic, M. (2015). The evaluation and improvement of process quality by using the fuzzy sets theory and genetic algorithm approach. Journal of Intelligent and Fuzzy Systems, 29(5), 2017-2028. doi:10.3233/ifs-151679

Pal, P., \& Kumar, B. (2008). "16T": Toward a dynamic vendor evaluation model in integrated SCM processes. Supply Chain Management: An International Journal, 13(6), 391-397. doi.org/10.1108/13598540810905642

Pathak, S. D., Day, J. M., Nair, A., Sawaya, W. J., \& Kristal, M. M. (2007). Complexity and adaptivity in supply networks: Building supply network theory using a complex adaptive systems perspective. Decision sciences, 38(4), 547-580. doi:10.1111/j.1540-5915.2007.00170.x

Pawlak, Z. (1998). Rough set theory and its applications to data analysis. Cybernetics \& Systems, 29(7), 661-688. doi. org/10.1080/019697298125470

Presutti, W. D. (2003). Supply management and e-procurement: Creating value added in the supply chain. Industrial marketing management, 32(3), 219-226. doi.org/10.1016/S00198501(02)00265-1
Ramesh, V., \& Kodali, R. (2012). A decision framework for maximising lean manufacturing performance. International Journal of Production Research, 50(8), 2234-2251. doi.org/10.10 80/00207543.2011.564665

Saaty, T. L. (1990). How to make a decision: The analytic hierarchy process. European journal of operational research, 48(1), 9-26. doi.org/10.1016/0377-2217(90)90057-I

Sadikoglu, E., \& Zehir, C. (2010). Investigating the effects of innovation and employee performance on the relationship between total quality management practices and firm performance: An empirical study of Turkish firms. International journal of production economics, 127(1), 13-26. doi. org/10.1016/j.ijpe.2010.02.013

Saranga, H., \& Moser, R. (2010). Performance evaluation of purchasing and supply management using value chain DEA approach. European Journal of Operational Research, 207(1), 197-205. doi.org/10.1016/j.ejor.2010.04.023

Shih, H. S., Shyur, H. J., \& Lee, E. S. (2007). An extension of TOPSIS for group decision making. Mathematical and Computer Modelling, 45(7), 801-813. doi.org/10.1016/j. mcm.2006.03.023

Tadic, D., Aleksic, A., Mimovic, P., Puskaric, H., \& Misita, M. (2016). A model for evaluation of customer satisfaction with banking service quality in an uncertain environment. Total Quality Management \& Business Excellence, 1-20. doi.org/10.10 80/14783363.2016.1257905

Tadić, D., Đorđević, A., Erić, M., Stefanović, M., \& Nestić, S. (2017). Two-step model for performance evaluation and improvement of New Service Development process based on fuzzy logics and genetic algorithm. Journal of Intelligent and Fuzzy Systems, 33(6), 3959-3970. doi:10.3233/jifs-17802

Wong, C. Y., \& Boon-itt, S. (2008). The influence of institutional norms and environmental uncertainty on supply chain integration in the Thai automotive industry. International Journal of Production Economics, 115(2), 400-410. doi. org/10.1016/j.jpe.2008.05.012

Xu, L., Li, Y., Govindan, K., \& Xu, X. (2015). Consumer returns policies with endogenous deadline and supply chain coordination. European Journal of Operational Research, 242(1), 88-99. doi.org/10.1016/j.ejor.2014.09.049 
Yoon, K., \& Hwang, C. L. (1981). Multiple attribute decision making: Methods and applications. Berlin, BRD: SpringerVerlag Berlin An. doi:10.1007/978-3-642-48318-9

Zadeh, L. (1975). The concept of a linguistic variable and its application to approximate reasoning. Information Sciences, 8(4), 301-357. doi.org/10.1016/0020-0255(75)90046-8

Zhai, L. Y., Khoo, L. P., \& Zhong, Z. W. (2009). Design concept evaluation in product development using rough sets and grey relation analysis. Expert Systems with Applications, 36(3), 7072-7079. doi.org/10.1016/j.eswa.2008.08.068
Zhang, Z., \& Zhang, S. (2017). Comments on "A note on "A novel approach to multi attribute group decision making based on trapezoidal interval type-2 fuzzy soft sets'"'. Applied Mathematical Modelling, 41, 702-710. doi.org/10.1016/j. apm.2016.09.011

Zimmermann, H. (2001). Fuzzy Sets Theory - And Its Applications. Amsterdam, Netherlands: Springer-Verlag. doi:10.1007/978-94-010-0646-0
Primljeno 17. novembra 2017, nakon revizije, prihvaćeno za publikovanje 22. decembra 2017. Elektronska verzija objavljena 29. decembra 2017.

Danijela Tadić je redovni profesor na Fakultetu inženjerskih nauka Univerziteta u Kragujevcu. Doktorirala je na Mašinskom fakultetu Univerziteta u Beogradu. Njene oblasti istraživanja su operaciona istraživanja i upravljanje lancima snabdevanja.

Aleksandar Đorđević je saradnik na Fakultetu inženjerskih nauka Univerziteta u Kragujevcu, gde je i doktorirao. Njegove oblasti istraživanja su operaciona istraživanja i informacioni menadžment. 


\title{
MODEL FOR THE SUPPLY CHAIN MANAGEMENT BASED ON THE INTERVAL TYPE-2 FUZZY NUMBERS AND THE TOPSIS METHOD
}

\author{
Danijela Tadic and Aleksandar Djordjevic \\ Faculty of Engineering, University of Kragujevac, Kragujevac, The Republic of Serbia
}

The Performance improvement that leads to an increase in business efficiency, both for the enterprises integrated in the supply chain and the entire supply chain, represents one of the basic strategic management problems. A solution to this problem, among other things, can be obtained by measuring and improving the performance of the supply chain, which simultaneously represents the basic purpose of this research study. The relative importance of performances and the values of their key performance indices are assessed by decision-makers. Their assessments are described by linguistic variables, which are modelled by interval fuzzy numbers type-2. The relative importance of performance is obtained by defining the fuzzy matrix of the relative importance of each pair of performances. The weight values of performances are calculated by means of the eigenvector method. Performance values are calculated by using the fuzzy middle-value operator. The rank of the enterprises, with respect to all of the considered performances as well as their weights, is determined by applying conventional TOPSIS. The ranking of the enterprises integrated in the supply chain can be marked as the main result of the research. On the basis of the obtained rank, appropriate measures can be taken to improve the performance of those enterprises that are rated the worst by respecting all the observed performances. The proposed model has been tested on the real life data from the automotive supply chain operating in Central Serbia.

Keywords: supply chain performance, interval type-2 fuzzy numbers, fuzzy AHP, TOPSIS, management measures

JEL Classification: C69, L62 